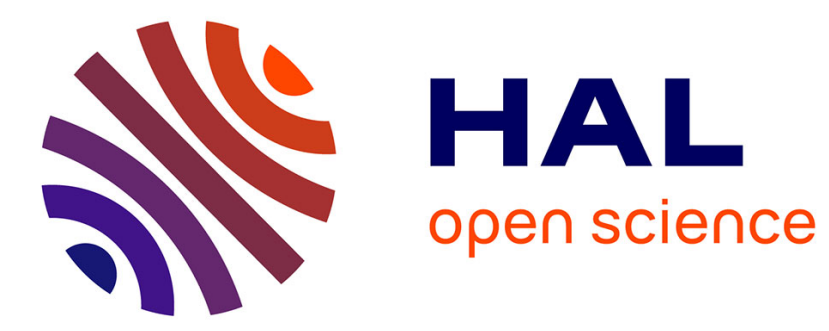

\title{
Hydrothermal Conversion of Uranium(IV) Oxalate into Oxides: A Comprehensive Study
}

J. Manaud, Jérôme Maynadie, Adel Mesbah, Myrtille Hunault, Philippe Martin, Morgan Zunino, Daniel Meyer, Nicolas Dacheux, Nicolas Clavier

\section{- To cite this version:}

J. Manaud, Jérôme Maynadie, Adel Mesbah, Myrtille Hunault, Philippe Martin, et al.. Hydrothermal Conversion of Uranium(IV) Oxalate into Oxides: A Comprehensive Study. Inorganic Chemistry, 2020, 10.1021/acs.inorgchem.9b03672 . hal-02491348

\section{HAL Id: hal-02491348 \\ https://hal.science/hal-02491348}

Submitted on 26 Feb 2020

HAL is a multi-disciplinary open access archive for the deposit and dissemination of scientific research documents, whether they are published or not. The documents may come from teaching and research institutions in France or abroad, or from public or private research centers.
L'archive ouverte pluridisciplinaire HAL, est destinée au dépôt et à la diffusion de documents scientifiques de niveau recherche, publiés ou non, émanant des établissements d'enseignement et de recherche français ou étrangers, des laboratoires publics ou privés. 


\section{Hydrothermal conversion of uranium(IV) oxalate into oxides : a comprehensive study}

Jérémie Manaud ${ }^{1}$, Jérôme Maynadié ${ }^{1}$, Adel Mesbah ${ }^{1}$, Myrtille O.J.Y. Hunault ${ }^{2}$, Philippe M. Martin ${ }^{3}$, Morgan Zunino ${ }^{1}$, Daniel Meyer ${ }^{1}$, Nicolas Dacheux ${ }^{1}$, Nicolas Clavier ${ }^{1, *}$

${ }^{1}$ ICSM, Univ Montpellier, CEA, CNRS, ENSCM, Bagnols-sur-Cèze, France

${ }^{2}$ Synchrotron SOLEIL, L'Orme des Merisiers, Saint Aubin BP 48, 91192 Gif-sur-Yvette, France

${ }^{3}$ CEA, DEN, DMRC, Univ Montpellier, Marcoule, France

* Corresponding author:

Dr. Nicolas CLAVIER

Institut de Chimie Séparative de Marcoule

Univ Montpellier, CEA, CNRS, ENSCM

Site de Marcoule

BP 17171

30207 Bagnols-sur-Cèze

France

Phone : + 33466339208

Fax : + 33466797611

nicolas.clavier@icsm.fr 


\begin{abstract}
:
Within the development of future nuclear reactors, wet chemistry routes have been investigated for the fabrication of advanced oxide fuels. In this frame, a multi-parametric study focused on the hydrothermal conversion of uranium(IV) oxalate $\mathrm{U}\left(\mathrm{C}_{2} \mathrm{O}_{4}\right)_{2} \cdot \mathrm{nH}_{2} \mathrm{O}$ into uranium oxides was undertaken in order to unravel the effects of temperature, $\mathrm{pH}$ and kinetics. For $\mathrm{pH} \leq 1$, the lowest temperatures explored (typically from 180 to $200^{\circ} \mathrm{C}$ ) led to stabilize $\mathrm{UO}_{2+\mathrm{x}} / \mathrm{U}_{4} \mathrm{O}_{9}$ mixtures exhibiting a global $\mathrm{O} / \mathrm{U}$ ratio evaluated to $2.38 \pm 0.10$ from $\mathrm{U}_{4}$-edge HERFDXANES experiments. Higher temperatures $\left(220-250^{\circ} \mathrm{C}\right)$ led the oxide stoichiometry to decrease down to $2.13 \pm 0.04$ which corresponds to a lower fraction of $\mathrm{U}_{4} \mathrm{O}_{9}$ in the mixture. Additionally, increasing the temperature of the hydrothermal treatment efficiently improved the elimination

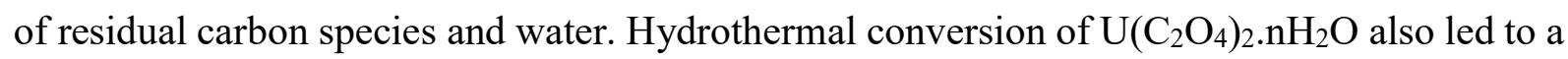
drastic modification of the powders morphology. With this aim, $\mathrm{pH}$ tuning could be used to shift from bipyramidal aggregates ( up to $\mathrm{pH}=1)$, microspheres $(2 \leq \mathrm{pH} \leq 5)$ then to nanometric powders $(\mathrm{pH}>5)$. Finally, a kinetics study showed that uranium oxides can be obtained from the hydrothermal decomposition of oxalate within only few hours. If the samples early collected during the treatment always presented the characteristic XRD lines of $\mathrm{UO}_{2+\mathrm{x}} / \mathrm{U}_{4} \mathrm{O}_{9}$ fluorite-type structure, they were found to be strongly oxidized $(\mathrm{O} / \mathrm{U}=2.65 \pm 0.14)$ which suggested the existence of a U(VI)-bearing amorphous secondary phase. This latter further tended to reduce through time. Hydrothermal conversion then probably proceeds as a two-step mechanism composed by the oxidative decomposition of uranium(IV) oxalate followed by the reduction of uranium by organic moieties and its hydrolysis. It appears as an easy and efficient way to yield highly pure uranium oxide samples in solution.
\end{abstract}




\section{Introduction}

Uranium dioxide $\left(\mathrm{UO}_{2}\right)$ is the most used nuclear fuel in Light Water Reactors (LWR). Additionally, some countries also employ actinide mixed oxides ( $\mathrm{MOx})$ such as $(\mathrm{U}, \mathrm{Pu}) \mathrm{O}_{2}$ in a number of LWR-type nuclear reactors and they still appear to be reference components for several future Generation IV designs, including Sodium-cooled Fast Reactor (SFR) ${ }^{1}$. Such concepts not only aim to increase the reactor safety but also to save uranium resources. As these objectives can be achieved by the means of a closed cycle, it is compulsory to set up fuel reprocessing and subsequent refabrication processes. In this frame, the use of wet chemistry methods is foreseen to replace powder metallurgy, with the aim to improve the homogeneity in the cations distribution within the final oxides ${ }^{2,3}$, and to reduce the amount of residual highly radioactive powder produced during fuel processing. Among the routes explored, the oxalic precipitation is certainly one of the most studied as revealed in a recent review ${ }^{4}$. Indeed, it provides quick, quantitative and homogenous precipitation of cations from aqueous mixtures and offer the possibility to incorporate simultaneously actinides with various oxidation states 5 , ${ }^{6}$. Moreover, the corresponding oxides are easily obtained through a heating conversion step ${ }^{7}$ 8 .

Despite these advantages, the resulting oxide powders suffer from some drawbacks which can impact their ability to form dense ceramic material during sintering process. First, the precipitation of An(IV) oxalates generally yields platelet-shape agglomerates. This morphology is further retained upon heating due to the isomorphic character of the oxalateoxide conversion ${ }^{9}$, and can lower the flowability of the final powder. Also, oxides coming from oxalate precursors were systematically found to present residual traces of carbon, typically from around $100 \mathrm{ppm}$ when calcined under air ${ }^{10}$ up to several thousands of ppm for thermal conversion performed under inert or reducing atmospheres ${ }^{9}$. Unfortunately, such residual carbon content was frequently associated to de-densification processes observed during the sintering step ${ }^{11,12}$.

In order to avoid these potential issues and to get the rid of the thermal conversion step, several studies recently investigated the use of hydrothermal conditions to directly achieve actinide oxide precipitation in solution. In such methods, the precipitation of the cations is ensured by the use of an organic complexing agent, which is further degraded in situ by the combined action of temperature and pressure. Simultaneously, actinides are hydrolyzed to form hydroxo- or oxohydroxo- species that finally age into oxides ${ }^{13}$. If some authors reported on the formation of spherical particles at the microscopic scale using aspartic acid or urea as 
complexing agents ${ }^{14-17}$, the use of oxalates was mostly related to the preparation of nanometric particles ${ }^{18}$. Also, the studies frequently focused on the morphology of the powders obtained and generally lacked from a complete chemical characterization. As a matter of example, the accurate stoichiometry of uranium(IV) oxides prepared through hydrothermal conversion of hydrothermal precursors was rarely assessed, although the authors aimed at preventing oxidation through the use of anti-nitrous agents ${ }^{19}$ or by working under inert atmosphere ${ }^{20}$.

On this basis, this paper is focused on the hydrothermal conversion of $\mathrm{U}\left(\mathrm{C}_{2} \mathrm{O}_{4}\right)_{2} \cdot \mathrm{nH}_{2} \mathrm{O}$ oxalate precursor into uranium oxides. A multi-parametric study was undertaken in order to unravel the effects of temperature, $\mathrm{pH}$ and kinetics and get advanced insights on the hydrothermal conversion mechanism. For all the samples prepared, a complete characterization was achieved at the structural, morphological and chemical levels. The variation of the crystallographic data correlatively to that of the $\mathrm{O} / \mathrm{U}$ ratio within the oxides as well as the presence of residual amounts of carbon and/or water was particularly investigated in order to finally suggest optimal conditions allowing the direct precipitation of pure uranium dioxides as close as possible from the stoichiometry.

\section{Experimental}

\subsection{Preparation of the samples}

All the reagents used were of analytical-grade and supplied by Sigma-Aldrich, except uranium metal chips that were kindly supplied by CETAMA. The preparation of uranium (IV) chloride solution was performed by dissolving uranium metal scraps in concentrated hydrochloric acid. The metal pieces were first rinsed with dichloromethane, acetone and water, washed in $2 \mathrm{M} \mathrm{HCl}$ in order to eliminate possible traces of uranium oxide formed at the surface, then finally dissolved in $6 \mathrm{M} \mathrm{HCl}$. Such a high hydrochloric acid concentration allowed us to maintain the tetravalent oxidation state of uranium in solution for several months ${ }^{21}$. The uranium concentration of the final solution was measured to $0.68 \pm 0.01 \mathrm{M}$ from ICP-AES measurements.

All the samples studied in this work were prepared from the precipitation of uranium(IV) oxalate and its subsequent conversion into oxide samples under mild hydrothermal conditions. The initial precipitation was obtained by mixing about $0.5 \mathrm{mmol}$ of tetravalent uranium in hydrochloric solution with a $50 \mathrm{~mol} . \%$ excess of $0.5 \mathrm{M}$ oxalic acid. Mixture of the 
reagents rapidly led to the formation of a greenish precipitate. Afterwards, both the solid phase and the supernatant were transferred in a Teflon-lined autoclave (Parr). Whatever the operating conditions tested, the volume of the solution was adjusted to $15 \mathrm{~mL}$ by adding $0.5 \mathrm{M} \mathrm{HCl}$ to avoid any bias due to autogenous pressure during the thermal treatment. The $\mathrm{pH}$ of the resulting solution was generally below 0.5 and was further adjusted by addition of diluted $\mathrm{NH}_{4} \mathrm{OH}$ and hydrochloric solution.

The reactor was finally sealed then heated between 130 to $250^{\circ} \mathrm{C}$ for 1 to 48 hours. As a matter of example, the pressure was close to 80 bars at $250^{\circ} \mathrm{C}^{22}$. The autoclave was cooled down naturally before collection of the final precipitate. This latter was separated by centrifugation at $14000 \mathrm{rpm}$, washed twice with deionized water and twice with ethanol then finally dried overnight at $90^{\circ} \mathrm{C}$ in an oven.

In parallel, the supernatant was analyzed by Photo-Electron Rejecting Alpha Liquid Scintillation (PERALS) to determine the residual uranium concentration and to calculate the precipitation yield. The extraction protocol described in our previous works ${ }^{23}$ was considered, using Alphaex ${ }^{\circledR}$ as the extracting phase (containing HDEHP, as the extractive molecule).

\subsection{Characterization of the samples}

PXRD. Powder X-Ray Diffraction (PXRD) patterns were obtained by the means of a Bruker D8 diffractometer equipped with a Lynxeye detector adopting the reflection geometry with Göbel mirror and using $\mathrm{Cu} \mathrm{K} \alpha_{1,2}$ radiation $\left(\lambda_{\text {average }}=1.54184 \AA\right)$. PXRD patterns were recorded at room temperature in the $5-100^{\circ}$ range $(2 \theta)$, a step size of $\Delta(2 \theta)=0.01^{\circ}$ and a total counting time of about 3 hours per sample. Powders were placed in a dedicated sample holder to avoid any radioactive contamination. This dome-shaped container equipped with an anti-scattering blade can lead to enhanced background in the $10-20^{\circ} 2 \theta$ range as well as small variations in peaks intensities. Pure silicon was collected as a standard and used to extract the instrumental function. All the PXRD patterns were refined by the Rietveld method using the Cox-Hastings pseudo-Voigt profile function ${ }^{24}$ implemented in the Fullprof_suite program ${ }^{25}$. During the refinements, the conventional profile/structure parameters (zero shift, unit cell parameters, scale factors, global thermal displacement and asymmetric parameters) were allowed to vary. Moreover, the modelling of the intrinsic microstructure parameters was performed by applying both an anisotropic size and strain model in agreement with the m-3m Laue class. 
X-ray absorption spectroscopy (XAS). X-ray absorption near edge structure (XANES) data were measured at the MARS beamline of the SOLEIL synchrotron (Saint-Aubin, France) ${ }^{26,27 .}$ The storage ring was operating in top-up mode at an electron current of $500 \mathrm{~mA}, 2.5 \mathrm{GeV}$. The beam size on sample was $150 \mu \mathrm{m} \times 150 \mu \mathrm{m}$ FWHM $(\mathrm{H} \times \mathrm{V})$. High-energy resolution fluorescence detected XANES (HERFD-XANES) was measured at the $\mathrm{U}_{4}$-edge $(3.7 \mathrm{keV})$ using the double-crystal monochromator (DCM) with a pair of $\mathrm{Si}(111)$ crystals. Higher harmonics rejection and vertical focusing was achieved using the Si strip of each mirror inserted before and after the DCM with a 4 mrad incidence angle. The incident energy was calibrated using the absorption K-edge of potassium of a $\mathrm{KBr}$ pellet (3.6 keV). The incident X-ray flux on the sample position was $1.9 \times 10^{9} \mathrm{ph} / \mathrm{s}$ at $3.5 \mathrm{keV}$. HERFD-XANES was measured using the crystal-analyzer $x$-ray spectrometer in the Rowland geometry and a KETEK single element silicon solid state detector. The M $\beta$ emission line $(3.339 \mathrm{keV})$ was analyzed using the 220 reflection of a $\mathrm{Si}(220)$ bent diced crystal analyzer with a curvature radius of $1 \mathrm{~m}$. The samples were oriented at $45^{\circ}$ with respect to the incident beam. A He-filled chamber was used to reduce the scattering of the incident and emitted x-rays by the air between the sample and the crystal analyzer and the detector. The overall energy resolution of the emission spectrometer was $1.1 \mathrm{eV}$ as determined from the FWHM of the elastic scattering peak at the double energy. Samples were prepared as pellets for each compound diluted in boron nitride. Thanks to the Athena Software, all spectra collected were normalized at the maximum of absorption, then they were fitted as a linear combination of different references to quantify the contribution of $\mathrm{U}(\mathrm{IV}), \mathrm{U}(\mathrm{V})$ and $\mathrm{U}(\mathrm{VI})$. All fits were obtained with a quality factor of $\mathrm{X}^{2}<0.04$. A $\mathrm{UO}_{2}$ single crystal provided by JRC Karlsruhe was chosen as pure U(IV) standard, while a $\mathrm{U}_{4} \mathrm{O}_{9}$ spectrum previously collected at the ESRF-ID26 beamline was used as a mixed standard for U(IV)/U(V) with a $1 / 1$ ratio ${ }^{28}$. This latter sample was obtained by solid-state chemistry from a mixture of $\mathrm{UO}_{2}$ and $\mathrm{U}_{3} \mathrm{O}_{8}$. Its homogeneity and stoichiometry were checked by neutron diffraction in similar conditions than our experiments (i.e. at room temperature and ambient pressure) ${ }^{29}$. Additionally, a $\mathrm{U}_{3} \mathrm{O}_{8}$ sample obtained by calcination of studtite $\left(\mathrm{UO}_{4} .4 \mathrm{H}_{2} \mathrm{O}\right)$ under air at $800^{\circ} \mathrm{C}$ for 5 hours was taken as a mixed standard for $\mathrm{U}(\mathrm{V}) / \mathrm{U}(\mathrm{VI})$ with a $2 / 1$ ratio ${ }^{28}$ while $\mathrm{UO}_{2}\left(\mathrm{NO}_{3}\right)_{2} \cdot 5 \mathrm{H}_{2} \mathrm{O}$ supplied by Prolabo was selected as pure U(VI) standard.

SEM observations. Before their observation, the samples were systematically deposited on carbon adhesive tape. Scanning Electron Microscope (SEM) micrographs were then directly recorded from the as-deposited powders without any additional preparation such as metallization. A FEI Quanta 200 scanning electron microscope, equipped with an Everhart- 
Thornley Detector (ETD) and a Back-Scattered Electron Detector (BSED) was used to record images with an acceleration voltage of $30 \mathrm{kV}$ under high vacuum conditions.

TG-MS Analyses. Thermogravimetric analyses coupled with mass spectrometry were undertaken thanks to a Setaram Setsys Evolution equipped with a type S thermocouple (Pt / Pt$10 \% \mathrm{Rh})$. After recording a baseline using an empty crucible $(100 \mu \mathrm{L})$, weight loss was measured with a $\mu \mathrm{g}$ precision during a heat treatment up to $1000^{\circ} \mathrm{C}$ with a rate of $5^{\circ} \mathrm{C} \cdot \mathrm{min}^{-1}$ under Ar atmosphere. Moreover, the gaseous species emitted during the heat treatment were analyzed by the means of Hiden Analytical QGA analyzer using mass spectrometry.

Carbon Analyses. The amount of residual carbon in the oxide powders was determined thanks to a LECO CS230 Carbon/Sulfur Determinator. In order to remove all adsorbed atmospheric $\mathrm{CO}_{2}$, the samples were first dried overnight at $90^{\circ} \mathrm{C}$ in an oven. Their complete combustion was then immediately performed under oxygen atmosphere and the concentration of $\mathrm{CO}_{2}$ was further determined by IR absorption. In order to recover quantitative values, a blank and a series of standards (steels containing 0.0013 to $5.02 \mathrm{wt} . \%$ of carbon) were analyzed prior our samples. 


\section{Results and discussion}

\subsection{Effect of temperature}

The effect of the hydrothermal treatment temperature on the physico-chemical properties of the powders prepared was first investigated between 130 and $250^{\circ} \mathrm{C}$ range. With this aim, the duration of the hydrothermal treatment was arbitrarily set to 24 hours whereas the $\mathrm{pH}$ of the reacting media remained uncontrolled and was then systematically found to be strongly acidic (i.e. $\mathrm{pH}<1$ ). Additionally, a sample that did not undergo any hydrothermal treatment was prepared and considered as a reference obtained at room temperature.

The samples obtained after hydrothermal treatment between 130 and $250^{\circ} \mathrm{C}$ were first characterized by PXRD (Figure 1). The reference sample prepared without any hydrothermal treatment confirmed the precipitation of $\mathrm{U}\left(\mathrm{C}_{2} \mathrm{O}_{4}\right)_{2} \cdot 2 \mathrm{H}_{2} \mathrm{O}$ from the mixture of $\mathrm{U}(\mathrm{IV})$ hydrochloric solution and oxalic acid. Indeed, the PXRD diagram collected presented all the XRD lines characteristic of the monoclinic structure (C2/c space group) reported by Clavier et al. ${ }^{30}$ (see the stick pattern in Figure 1a). Also, although one should have expect the formation of the hexahydrate compound $\mathrm{U}\left(\mathrm{C}_{2} \mathrm{O}_{4}\right)_{2} \cdot 6 \mathrm{H}_{2} \mathrm{O}^{31}$, the hydration rate was in our case lowered by the drying step operated at $90^{\circ} \mathrm{C} 32,33 \cdot \mathrm{U}\left(\mathrm{C}_{2} \mathrm{O}_{4}\right)_{2} \cdot 2 \mathrm{H}_{2} \mathrm{O}$ was further maintained when applying hydrothermal treatments up to $160^{\circ} \mathrm{C}$. A slight modification of the PXRD diagram was noted at $170^{\circ} \mathrm{C}$, with the appearance of additional XRD lines near to 17,29 and $34^{\circ}$. Such transformation was likely to be due to the partial dehydration of the oxalate. As no data was reported in the literature for $\mathrm{U}\left(\mathrm{C}_{2} \mathrm{O}_{4}\right)_{2} \cdot \mathrm{nH}_{2} \mathrm{O}$ compounds with $\mathrm{n}<2$, the identification of the patterns was made from the work of Dash et al. on the thorium analogues ${ }^{34}$. It led to assign the supplementary phase to $\mathrm{U}\left(\mathrm{C}_{2} \mathrm{O}_{4}\right)_{2} \cdot \mathrm{H}_{2} \mathrm{O}$. 


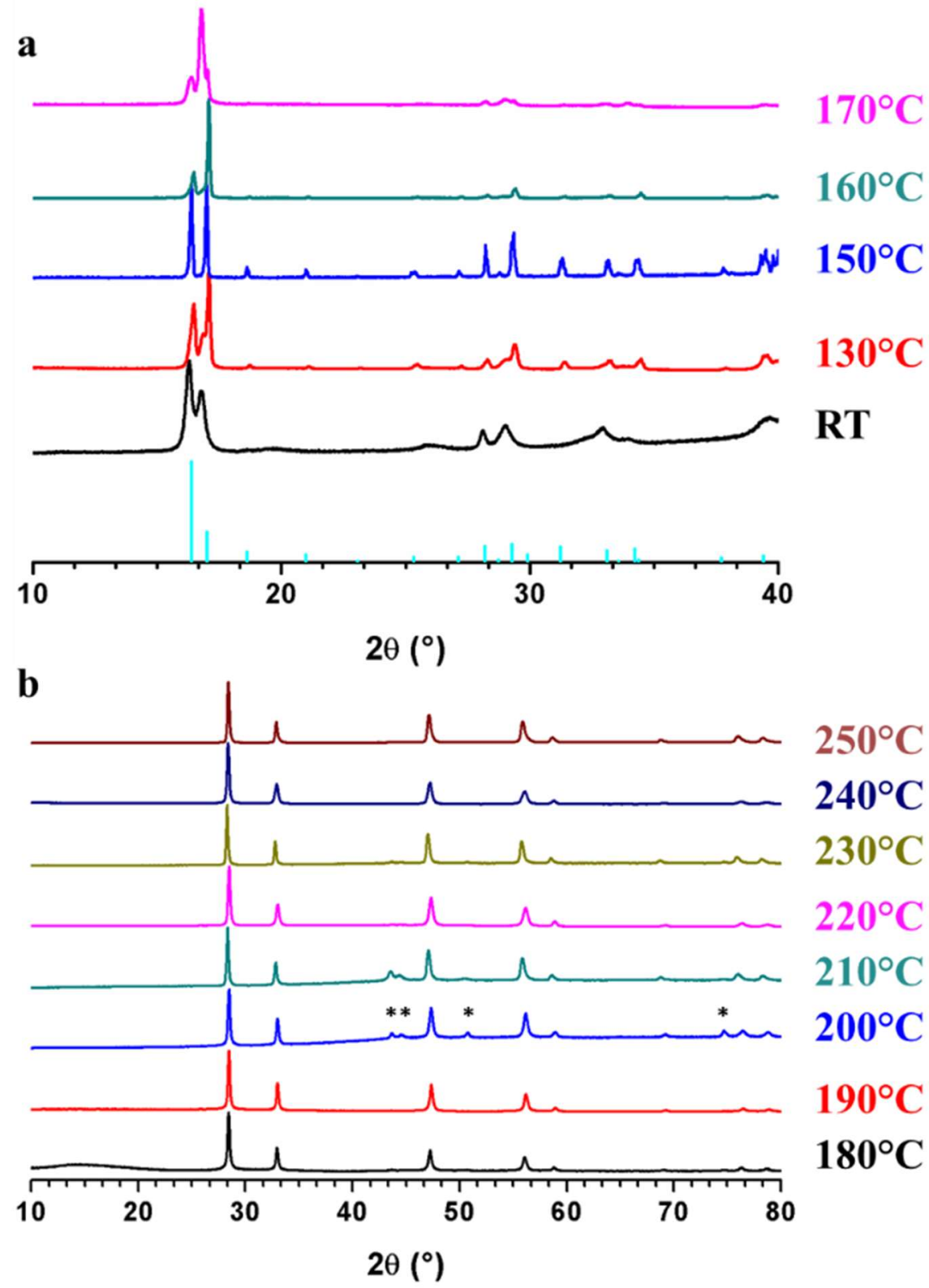

Figure 1. $\mathrm{XRD}$ diagrams obtained after hydrothermal treatment of $\mathrm{U}\left(\mathrm{C}_{2} \mathrm{O}_{4}\right)_{2} \cdot \mathrm{nH}_{2} \mathrm{O}$ at various temperatures during $24 \mathrm{~h}$ : a) $\mathrm{RT}-170^{\circ} \mathrm{C}$, b) $180^{\circ} \mathrm{C}-250^{\circ} \mathrm{C}$. Stick pattern in figure a) is taken from PDF data file \#01-078-7197. * : signal assigned to the sample holder.

In contrast, all the PXRD patterns recorded for samples prepared for temperatures higher than $180^{\circ} \mathrm{C}$ were found to present all the characteristic $\mathrm{XRD}$ lines of $\mathrm{UO}_{2+\mathrm{x}}$ (fluorite-type structure) ${ }^{35}$. The hydrothermal conversion of the oxalate species then occurred on a very narrow temperature range. This observation was backed up by the determination of the uranium(IV) precipitation yield (Figure 2). Indeed, for the lowest temperatures investigated (i.e. up to $130^{\circ} \mathrm{C}$ ), the precipitation yield remained close to the value determined for the oxalate obtained at RT and can be considered as almost quantitative, in good agreement with the 
abundant literature dedicated to uranium oxalates ${ }^{36,37}$. The synthesis yield was then found to drastically decrease down to only $15 \%$ at around $170^{\circ} \mathrm{C}$, which marked the transition from oxalate to oxide. This temperature was in good agreement with the literature, since Crossey reported the decomposition of aqueous oxalate species in the $180-230^{\circ} \mathrm{C}$ range ${ }^{38}$. Oxalates were found to evolve to formic acid species following a first-order kinetic law, the reaction rate being increased for low $\mathrm{pH}$ values and high temperatures.

For higher temperatures, the synthesis yield increased progressively between 180 and $200^{\circ} \mathrm{C}$ then stabilized up to $250^{\circ} \mathrm{C}$ to reach about $70 \%$. U(IV) was then partly precipitated in these conditions, which could be explained by the very low $\mathrm{pH}$ of the solution (i.e. $\mathrm{pH}<1$ ). Indeed, after the initial decomposition of the oxalate moieties, the formation of the oxide was likely to occur through the formation of hydroxides, which further rapidly aged to form $\mathrm{UO}_{2+x} \cdot \mathrm{nH}_{2} \mathrm{O}$. This mechanism was already depicted by several authors ${ }^{14,39}$. Rai et al. already reported that such reaction operated at room temperature for $\mathrm{pH}>2^{40}$, while the solubility of amorphous $\mathrm{UO}_{2}$ did not sustain important variation up to $300^{\circ} \mathrm{C}{ }^{13}$. The formation of $\mathrm{U}(\mathrm{OH})_{4}$ (i.e. total hydrolysis of $\mathrm{U}^{4+}$ ) was then incomplete in our experimental conditions, which tended to lower the precipitation yield. As the starting $\mathrm{pH}$ of the solution appeared as a very important parameter to consider, a detailed study will be presented in the next section of this paper.

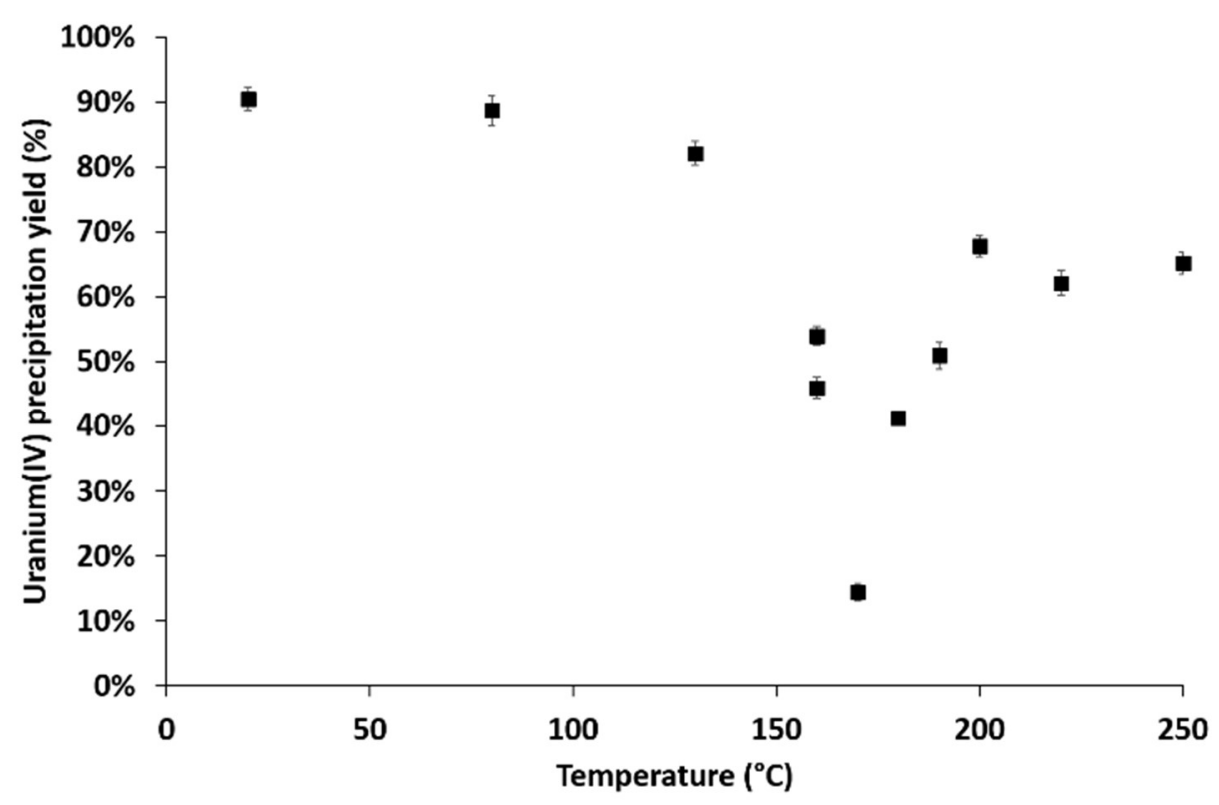

Figure 2. Variation of the U(IV) precipitation yield as a function of hydrothermal treatment temperature $(\mathrm{pH}<1, \mathrm{t}=24$ hours $)$, determined from PERALS analyses of the supernatant. 
In order to complete the structural characterization of the uranium oxide samples, Rietveld refinements of the PXRD patterns were performed in order to extract unit cell volumes and average crystallite sizes (Figure 3). It is to note that in some cases, duplicates coming from distinct synthesis batches were analyzed in order to check the reliability of our results. As shown in the review from McEachern and Taylor, at temperatures below $400^{\circ} \mathrm{C}$, oxidation of uranium only led to limited over-stoichiometry in the fluorite structure of uranium dioxide (typically up to $\mathrm{x}=0.05$ ) and then quickly yielded complex mixtures of $\mathrm{UO}_{2+\mathrm{x}}, \mathrm{U}_{4} \mathrm{O}_{9}$ and even $\mathrm{U}_{3} \mathrm{O}_{7}{ }^{41}$. Nevertheless, typical features of $\mathrm{U}_{3} \mathrm{O}_{7}$ XRD pattern (such as the splitting of diffraction lines located around 32.5 and $\left.47^{\circ}\right)^{42,43}$ were never observed in our samples. Conversely, the presence of $\mathrm{U}_{4} \mathrm{O}_{9}$, which crystallizes in a superlattice derived from the fluorite-type structure, cannot be discarded using a classical laboratory PXRD apparatus ${ }^{42-44}$. In this structure, additional oxygen atoms are accommodated in cuboctahedral clusters that depend on the stabilized form (i.e. $\alpha, \beta$ or $\gamma)^{29,45}$. Hence, the similarity of $\mathrm{UO}_{2+\mathrm{x}}$ and $\mathrm{U}_{4} \mathrm{O}_{9}$ XRD patterns, combined with the limited resolution of our XRD data, precludes any phase quantification in the hypothesis of a $\mathrm{UO}_{2+\mathrm{x}} /$ $\mathrm{U}_{4} \mathrm{O}_{9}$ mixture. As a preliminary approach, only one fluorite-type structure, corresponding to a single $\mathrm{UO}_{2+x}$ phase, was then considered in the fitting procedure. Therefore, the derived lattice parameter is merely a qualitative indicator of the oxide stoichiometry, i.e. of uranium oxidation state.

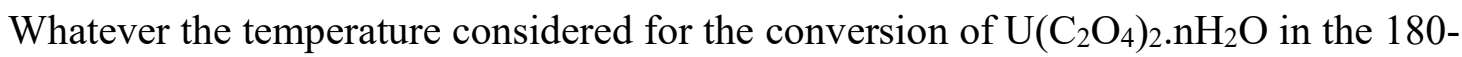
$250^{\circ} \mathrm{C}$ range, the unit cell volume was systematically found to be lower than the reference value recently reported by Leinders et al. for $\mathrm{UO}_{2.00}{ }^{46}\left(163.781 \AA^{3}\right)$. This clearly indicated the formation of hyper-stoichiometric oxides, as the unit cell volume of $\mathrm{UO}_{2+\mathrm{x}}$ was reported for long to vary from $163.5-163.8 \AA^{3}$ for $\mathrm{UO}_{2.00}{ }^{47,48}$ to around $161.0 \AA^{3}$ for $\mathrm{O} / \mathrm{U}$ ratios close to 2.25 ${ }^{49-51}$, which constitute the upper limit of the fluorite-type structure $\left(\mathrm{UO}_{2.25}\right.$ being indexed in the R3c or the I-43d space group depending on the temperature considered ${ }^{29}$ ). Thus, two ranges of temperatures can be distinguished depending on the value of the unit cell volume.

From 180 to $210^{\circ} \mathrm{C}$, all the hydrothermal synthesis performed led to unit cell volumes below the limit value of $161.0 \AA^{3}$, which could be interpreted as a strong increase of the $\mathrm{O} / \mathrm{U}$ ratio in the samples. On this basis, one must envisaged that the use of hydrothermal conditions, combined with the submicrometric size of the powders (see below) might stabilize a fluoritederived structure towards higher values of $\mathrm{O} / \mathrm{M}$ ratio. Indeed, cubic $\mathrm{UO}_{2+\mathrm{x}}$ with $\mathrm{x}=0.24-0.5$ was already reported after oxidation of ultra-fine $\mathrm{UO}_{2.00}$ under air at room temperature ${ }^{43,52}$. In the $220-250^{\circ} \mathrm{C}$ range, the unit cell volume of the samples prepared was further found to increase, which could be seen as a decrease of the $\mathrm{O} / \mathrm{U}$ ratio in hyper-stoichiometric $\mathrm{UO}_{2+\mathrm{x}}$ 
samples, or of the $\mathrm{U}_{4} \mathrm{O}_{9}$ amount in $\mathrm{UO}_{2+\mathrm{x}} / \mathrm{U}_{4} \mathrm{O}_{9}$ mixtures. However, the direct correlation of the lattice parameters with an accurate value of $x$ remains difficult in such a complex multiphase system.

Additionally, the variation of the crystallites size (Figure 3b) was also monitored. Even if the values obtained tend to be underestimated when considering a single fluorite-type structure instead of the real multiphase system, a general trend can be discussed. In the 180$210^{\circ} \mathrm{C}$ range, the crystallites size was first found to remain mostly constant and close to 30-40 $\mathrm{nm}$. For higher temperatures of hydrothermal treatment, growth processes were activated and led to crystallites sizes up to $90 \mathrm{~nm}$. Such a two-step behavior was usually observed during the thermal conversion of An(IV)-based oxalates ${ }^{53}$ as well as for nanocrystals growth of $\mathrm{AnO}_{2}{ }^{54}$. Moreover, no clear correlation was established between the variation of the oxide stoichiometry and that of the crystallites size. The $\mathrm{O} / \mathrm{U}$ ratio was then probably a second-order parameter compared to temperature regarding crystallites growth.

a)

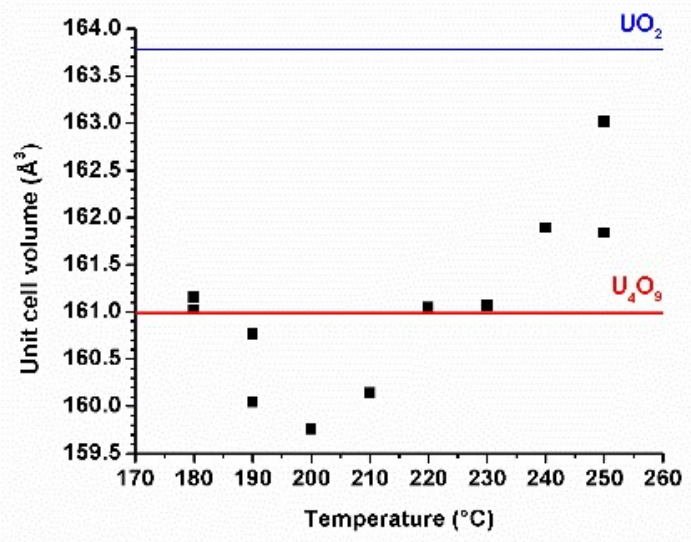

b)

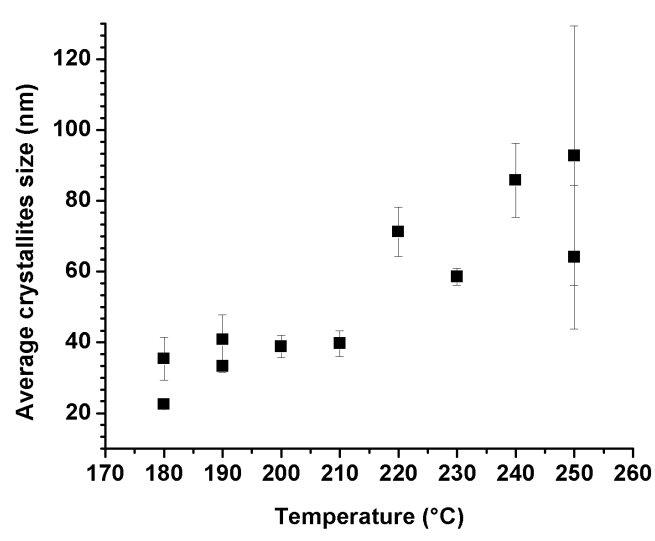

Figure 3. Variation of the unit cell volume (a) and of the average crystallites size (b) of uranium oxide (considered as a single fluorite-type structure) versus temperature of hydrothermal treatment $(\mathrm{pH}<1, \mathrm{t}=24 \mathrm{~h})$. Reference values for $\mathrm{UO}_{2}$ and $\mathrm{U}_{4} \mathrm{O}_{9}$ are taken from references ${ }^{46}$ and ${ }^{45}$, respectively.

In order to get further insights on the $\mathrm{O} / \mathrm{U}$ stoichiometry of the oxide produced by

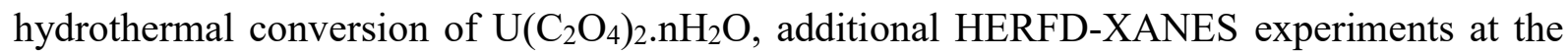
uranium $\mathrm{M}_{4}$-edge ${ }^{28}$ were undertaken on selected samples as well as on $\mathrm{UO}_{2}, \mathrm{U}_{4} \mathrm{O}_{9}$ and $\mathrm{U}_{3} \mathrm{O}_{8}$ references (Figure 4). As expected, $\mathrm{UO}_{2}$ only presented one large peak corresponding to U(IV) whereas $\mathrm{U}_{4} \mathrm{O}_{9}$ exhibits two peaks with similar intensities corresponding to $\mathrm{U}(\mathrm{IV})$ and $\mathrm{U}(\mathrm{V})$ contributions. Comparatively, $\mathrm{U}_{3} \mathrm{O}_{8}$ presented a large signal located around $3727 \mathrm{eV}$ that accounted for $\mathrm{U}(\mathrm{V})$ and $\mathrm{U}(\mathrm{VI})$. As already demonstrated by Leinders et $a l .{ }^{55}$, the different peaks 
are well separated in energy with this technique, which allowed us to investigate accurately the oxidation state of uranium in our samples.

All the spectra recorded on oxides prepared after hydrothermal conversion of uranium(IV) oxalate between 200 and $250^{\circ} \mathrm{C}$ presented two distinct peaks, which accounted for a mixed U(IV) / U(V) valence in these compounds. Nevertheless, the intensity of the two peaks was systematically found to be uneven, which excluded the simple formation of $\mathrm{U}_{4} \mathrm{O}_{9}$. Also, one must note that the presence of uranyl entities was discarded in these samples due to the absence of band around $3733 \mathrm{eV}$. Moreover, significant differences were noted between the sample obtained at $200^{\circ} \mathrm{C}$, and those synthesized at higher temperatures. On the one hand, the sample prepared at $200^{\circ} \mathrm{C}$ displayed a U(V) contribution significantly higher than the U(IV) one. A very slight band around $3732 \mathrm{eV}$ can also be distinguished and accounted for the presence of limited amount of U(VI) in the system. Conversely, the U(IV) was found to be predominant in samples prepared at $220^{\circ} \mathrm{C}, 240^{\circ} \mathrm{C}$ and $250^{\circ} \mathrm{C}$.

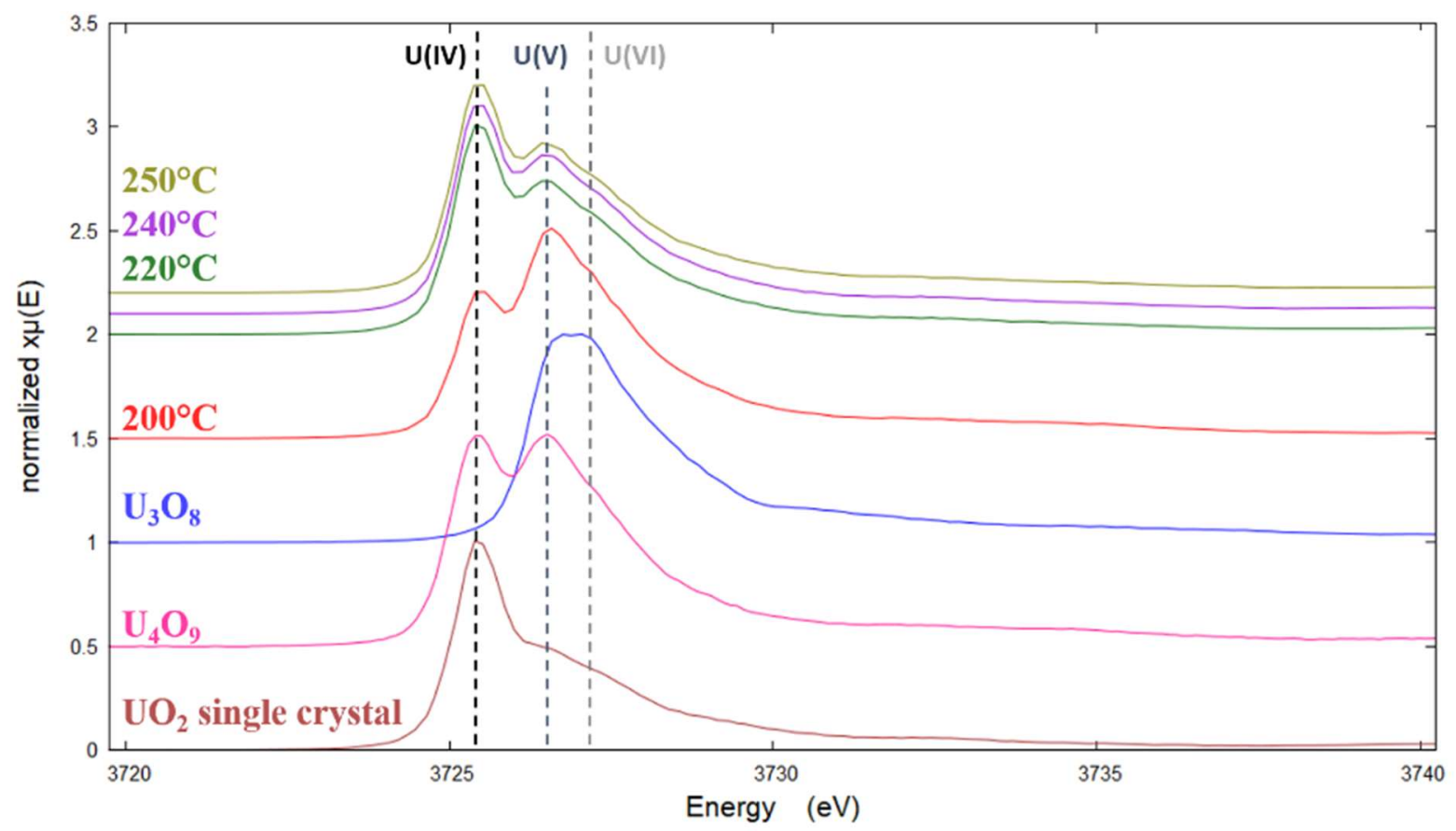

Figure 4. Normalized HERFD-XANES spectra of reference samples and of oxide samples obtained after hydrothermal treatment of $\mathrm{U}\left(\mathrm{C}_{2} \mathrm{O}_{4}\right)_{2} \cdot \mathrm{nH}_{2} \mathrm{O}$ at various temperatures for 24 hours at $\mathrm{pH}<1$.

The contribution of U(IV), U(V) and U(VI) was then quantified by fitting the collected spectra as a linear combination of the three references (Table 1). For the sample prepared at $200^{\circ} \mathrm{C}$, the spectrum was only correctly fitted by considering the three different oxidation states 
of uranium. On the contrary, satisfactory fit was obtained by using only a combination of $\mathrm{UO}_{2}$ and $\mathrm{U}_{4} \mathrm{O}_{9}$ for samples synthesized between 220 and $250^{\circ} \mathrm{C}$. With these results, the global $\mathrm{O} / \mathrm{U}$ ratio in the samples was estimated to $2.38 \pm 0.10$ at $200^{\circ} \mathrm{C}$ and close to $2.13 \pm 0.04$ in the 220$250^{\circ} \mathrm{C}$ range. Based on the $\mathrm{U}-\mathrm{O}$ phase diagram reported by Guénau et al. ${ }^{56}$, the sample prepared at $200^{\circ} \mathrm{C}$ should then correspond to a mixture between $\mathrm{U}_{3} \mathrm{O}_{7}$ and $\mathrm{U}_{3} \mathrm{O}_{8}$. Nevertheless, as mentioned previously, the presence of these phases was discarded from the XRD analysis. The use of hydrothermal conditions then allowed to stabilize the cubic structure of $\mathrm{UO}_{2+\mathrm{x}} / \mathrm{U}_{4} \mathrm{O}_{9}$ up to higher $\mathrm{O} / \mathrm{U}$ ratios. On the contrary, the samples prepared at higher temperatures presented a stoichiometry corresponding to a mixture of approximately $60 \% \mathrm{UO}_{2.05}$ and $40 \% \mathrm{U}_{4} \mathrm{O}_{9}$, which is in good agreement with the XRD patterns recorded.

Table 1. Uranium oxidation state distribution obtained from the linear combination fitting of HERFD-XANES spectra.

\begin{tabular}{cccccc}
\hline Temperature $\left({ }^{\circ} \mathbf{C}\right)$ & $\mathbf{U}(\mathbf{I V})(\%)$ & $\mathbf{U}(\mathbf{V})(\%)$ & $\mathbf{U}(\mathbf{V I})(\%)$ & O/U ratio & $\begin{array}{c}\text { Average } \mathbf{U} \\
\text { oxidation state }\end{array}$ \\
\hline 200 & $36.0 \pm 1.8$ & $52.5 \pm 1.8$ & $11.5 \pm 0.6$ & $2.38 \pm 0.10$ & 4.8 \\
220 & $76.3 \pm 1.5$ & $23.7 \pm 0.5$ & 0 & $2.12 \pm 0.04$ & 4.2 \\
240 & $73.8 \pm 1.4$ & $26.2 \pm 0.4$ & 0 & $2.13 \pm 0.04$ & 4.3 \\
250 & $74.9 \pm 1.1$ & $25.1 \pm 0.4$ & 0 & $2.13 \pm 0.03$ & 4.3 \\
\hline
\end{tabular}

The oxide samples prepared by hydrothermal conversion of $\mathrm{U}\left(\mathrm{C}_{2} \mathrm{O}_{4}\right)_{2} \cdot \mathrm{nH}_{2} \mathrm{O}$ between 180 and $250^{\circ} \mathrm{C}(\mathrm{pH}<1 ; \mathrm{t}=24$ hours $)$ were further characterized from the morphological and chemical points of view. With this aim, SEM images were collected for selected samples (Figure 5). While the oxalate samples retained their classical platelet-like habit up to $170^{\circ} \mathrm{C}$, the conversion towards oxides marked a drastic modification in the powders morphology. Indeed, as soon as $180^{\circ} \mathrm{C}$, the powders were found to be formed by bipyramid-shape aggregates of about $1 \mu \mathrm{m}$ in length. These objects were composed by smaller crystallites of about $40 \mathrm{~nm}$, as evidenced from PXRD data refinement, and then possessed a hierarchical microstructure, which was frequently observed in samples obtained through hydrothermal methods ${ }^{14,15}$. The use of hydrothermal conditions then allowed to get rid of the usual platelet-like morphology of An(IV) oxalates, which is expected to be poorly suitable for shaping and sintering and was always retained by using isomorphic thermal conversion. Also, it is worth noting that this morphology slightly differed from that reported by Balice et al. during the preparation of Anbased oxides by hydrothermal conversion of oxalate precursors, which were mostly nanometric 
powders ${ }^{19}$. This differnce probably arose from variations in the synthesis protocols. Indeed, Balice et al. first separated the initial oxalate precipitate from the supernatant then poured it into a mixture of deionized water and hydrazine to perform their final conversion. The concentrations of organic species in the reacting media, which were frequently depicted as shaping agents ${ }^{16}$, were then lower than that obtained in this work. Consequently, the aggregation of the nanocrystallites was most probably disadvantaged.

The size and the shape of the aggregates obtained was further maintained up to $220^{\circ} \mathrm{C}$, although the inner porosity substantially increased, thereby increasing the roughness. Such modification of the aggregates microstructure was correlated to the increase of the average crystallite size with temperature, as already evidenced by PXRD measurements. In contrast, the particles obtained at $250^{\circ} \mathrm{C}$ were found to be smaller with sizes typically between 200 and 500 $\mathrm{nm}$. This feature was likely to be linked with the kinetics of oxalate degradation which was fastened by the rise of temperature and probably favored the nucleation of isolated particles.
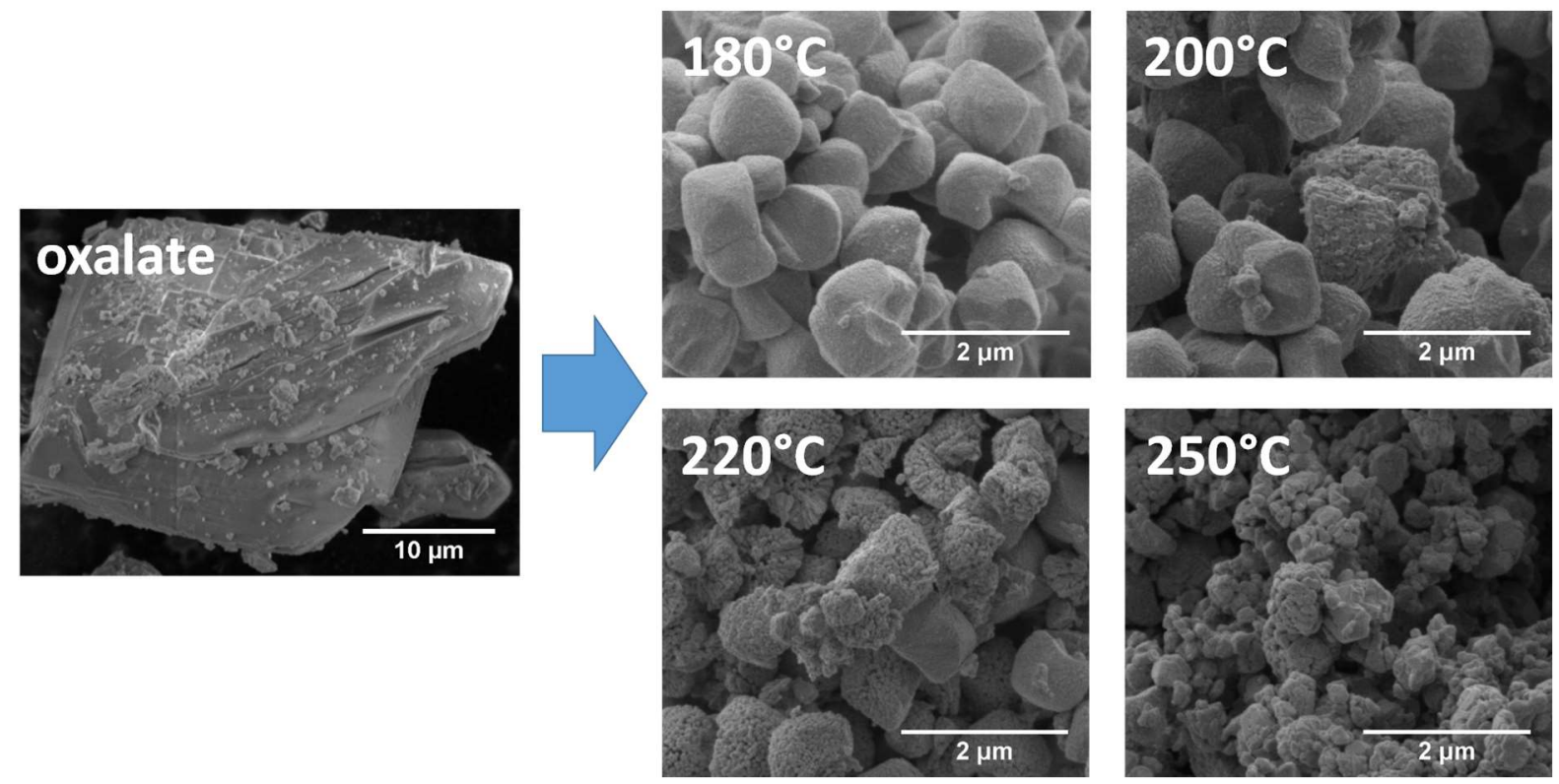

Figure 5. SEM images of uranium dioxide synthesized by hydrothermal treatment of $\mathrm{U}\left(\mathrm{C}_{2} \mathrm{O}_{4}\right)_{2} \cdot \mathrm{nH}_{2} \mathrm{O}(\mathrm{pH}<1, \mathrm{t}=24 \mathrm{~h})$ at various temperatures and comparison with original oxalate precursor.

The presence of impurities coming from the hydrothermal degradation of $\mathrm{U}\left(\mathrm{C}_{2} \mathrm{O}_{4}\right)_{2} \cdot \mathrm{nH}_{2} \mathrm{O}$ was finally checked in the oxide samples. Indeed, previous works showed that the presence of residual carbon in the oxide powders could impact negatively the densification step $^{9,11,12}$. Powders were then first characterized thanks to a carbon analyzer (Table 2). After heating at $180^{\circ} \mathrm{C}$, the residual carbon content within the oxide powders reached $0.82 \pm 0.01$ wt.\%. Such a huge amount might indicate that the decomposition of oxalate species was still 
incomplete, even if only fluorite-type oxides were detected by PXRD. Also, amorphous carbon or carbonate species could be trapped either within the oxide structure or between the crystallites forming the aggregates. Nevertheless, the carbon content was found to quickly drop down with temperature. Indeed, it was found to $0.12 \pm 0.02 \mathrm{wt} . \%$ after heating at $200^{\circ} \mathrm{C}$, which was lower than the value measured by Martinez et al. in $\mathrm{UO}_{2+\mathrm{x}}$ oxides coming from direct conversion of $\mathrm{U}\left(\mathrm{C}_{2} \mathrm{O}_{4}\right)_{2} .2 \mathrm{H}_{2} \mathrm{O}$ under reducing atmosphere at $1000^{\circ} \mathrm{C}$ (i.e. 0.2 wt.\%) ${ }^{9}$. Beyond $220^{\circ} \mathrm{C}$, the value became even lower and decreased by about one order of magnitude to reach 100-200 ppm. Such amount was close to that generally reported for oxides prepared through the calcination of oxalate precursors under oxidizing atmospheres $9,10,57$, which strongly favors the elimination of carbon through the Boudouard equilibrium $\left(\mathrm{C} / \mathrm{CO} / \mathrm{CO}_{2}\right)$. Also, it satisfies to the ASTM C753 standard which state the upper limit (100 ppm) for C impurities in nucleargrade sinterable uranium oxide powders ${ }^{58}$. The use of mild hydrothermal conditions then appears as a powerful way to eliminate carbon residues from the samples and yields highlypure uranium dioxide samples.

Table 2. Carbon content (expressed in wt.\%) and water content (expressed in mol. per mole of oxide) obtained in uranium oxide samples resulting from hydrothermal conversion of $\mathrm{U}\left(\mathrm{C}_{2} \mathrm{O}_{4}\right)_{2} \cdot \mathrm{nH}_{2} \mathrm{O}$ for various temperatures $(\mathrm{pH}<1, \mathrm{t}=24 \mathrm{~h})$.

\begin{tabular}{ccccc}
\hline $\mathbf{T}\left({ }^{\circ} \mathbf{C}\right)$ & $\begin{array}{c}\text { Total weight } \\
\text { loss at } \mathbf{1 0 0 0}^{\circ} \mathbf{C}(\%)\end{array}$ & $\mathbf{C}($ wt. $\%)$ & $\mathbf{H}_{2} \mathbf{O}(w t . \%)$ & $\begin{array}{c}\mathrm{H}_{2} \mathrm{O} \\
\text { (mol. per unit formula) }\end{array}$ \\
\hline 180 & $5.00 \pm 0.05$ & $0.82 \pm 0.01$ & $4.18 \pm 0.05$ & $0.66 \pm 0.01$ \\
200 & $2.75 \pm 0.05$ & $0.12 \pm 0.02$ & $2.63 \pm 0.05$ & $0.41 \pm 0.01$ \\
220 & $0.80 \pm 0.05$ & $0.01 \pm 0.03$ & $0.79 \pm 0.06$ & $0.12 \pm 0.01$ \\
240 & $0.50 \pm 0.05$ & $0.02 \pm 0.03$ & $0.48 \pm 0.06$ & $0.07 \pm 0.01$ \\
250 & $0.80 \pm 0.05$ & $<0.01$ & $0.80 \pm 0.05$ & $0.12 \pm 0.01$ \\
\hline
\end{tabular}

Additionally, thermogravimetric experiments were undertaken under inert atmosphere (Ar) to monitor the elimination of residual carbon and to assess the water content in the prepared powders (Figure 6). As expected from the carbon analyses, the sample prepared at $180^{\circ} \mathrm{C}$ exhibited the highest weight loss, even if this latter remained limited to only a few percent. The mass loss was found to start at $100^{\circ} \mathrm{C}$. It was first assigned to the departure of water molecules based on MS analyses. Above $250^{\circ} \mathrm{C}$ and up to about $350^{\circ} \mathrm{C}$, a sharp decrease of the weight loss was observed. It was associated to the elimination of residual carbon as a mixture of $\mathrm{CO}$ and $\mathrm{CO}_{2}$. This range of temperature appeared to be lower than that reported by Martinez et al. when studying the thermal behavior of uranium(IV)-cerium(IV) hydrated oxides ${ }^{39}$, which once 
again argues for the rapid and efficient elimination of carbon species through a hydrothermal process. A continuous mass loss was then recorded up to $600^{\circ} \mathrm{C}$ and was assigned to the elimination of water molecules. Based on a total weight loss of about $4 \%$ and considering the contribution coming from carbon species, the hydration rate of the sample was then found to be close to $0.7 \mathrm{H}_{2} \mathrm{O}$ per mole of $\mathrm{UO}_{2+x}$. This low value agreed well with the mechanism proposed for the formation of $\mathrm{UO}_{2+\mathrm{x}} \cdot \mathrm{nH}_{2} \mathrm{O}$ samples, i.e. hydrolysis of $\mathrm{U}(\mathrm{IV})$ as $\mathrm{U}(\mathrm{OH})_{4}$ after hydrothermal conversion of $\mathrm{U}\left(\mathrm{C}_{2} \mathrm{O}_{4}\right)_{2} \cdot \mathrm{nH}_{2} \mathrm{O}$, followed by its rapid aging to form hydrated uranium oxide. Indeed, even if the evolution of uranium(IV) tetrahydroxide should yield $\mathrm{UO}_{2} \cdot 2 \mathrm{H}_{2} \mathrm{O}$, it is known to further partially dehydrate as the number of water molecules reported in the literature for such compounds is generally between 0 and $2^{13}$. This dehydration was even more pronounced at $200^{\circ} \mathrm{C}$, and led to $0.4 \mathrm{H}_{2} \mathrm{O}$ per formula unit.

For higher temperatures of hydrothermal treatment, a very low weight loss, that did not exceed $0.7 \%$, was observed. As the carbon content was almost negligible in these conditions, the mass loss was mainly assigned to water molecule, leading to hydration ratio of about 0.1 $\mathrm{H}_{2} \mathrm{O}$ per formula unit. Nevertheless, one must keep in mind that partial reduction of the samples could also occur when heating in highly pure argon atmosphere. In these conditions, the total reduction of $\mathrm{UO}_{2.12}$ into $\mathrm{UO}_{2.00}$ would also account for a weight loss of about $0.7 \%$. As the dehydration of the oxide sample and its reduction probably process concomitantly, it was then difficult to accurately conclude on the hydration of the sample. Nevertheless, owing to the value determined, they can be considered as almost anhydrous.

a)

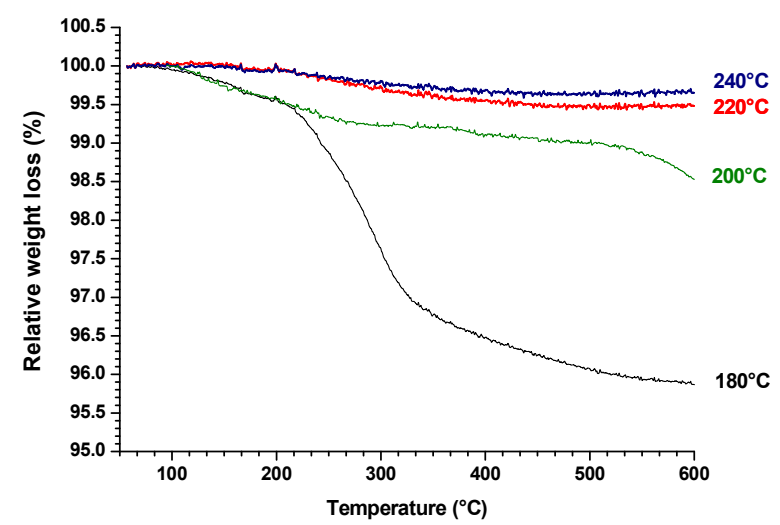

b)

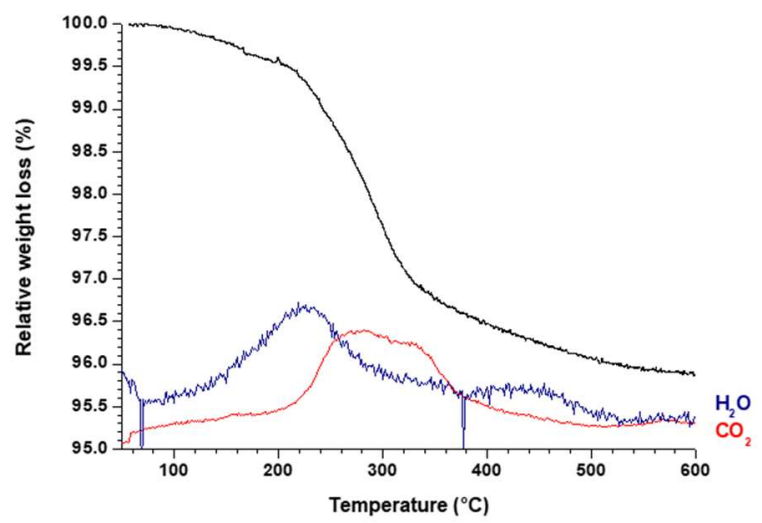

Figure 6. TG analyses of $\mathrm{UO}_{2+\mathrm{x}} \cdot \mathrm{nH}_{2} \mathrm{O}$ samples synthesized by hydrothermal conversion of $\mathrm{U}\left(\mathrm{C}_{2} \mathrm{O}_{4}\right)_{2} \cdot \mathrm{nH}_{2} \mathrm{O}(\mathrm{pH}<1, \mathrm{t}=24 \mathrm{~h})$ at $180,200,220$ and $240^{\circ} \mathrm{C}$ (a). Associated mass spectroscopy analyses of emitted gases $\left(\mathrm{H}_{2} \mathrm{O}: \mathrm{m} / \mathrm{z}=18 ; \mathrm{CO}_{2}: \mathrm{m} / \mathrm{z}=44\right)$ for the sample prepared at $180^{\circ} \mathrm{C}(\mathrm{b})$. 


\subsection{Effect of initial pH}

In order to improve the uranium precipitation yield and to control the morphology of the final powder, a second study was dedicated to the effect of $\mathrm{pH}$ value in the starting mixtures. Based on our previous results, the hydrothermal treatment temperature was fixed to $250^{\circ} \mathrm{C}$, which corresponded to the samples presenting the lowest $\mathrm{O} / \mathrm{U}$ ratio as well as the lowest contents of residual carbon and water. The duration of the hydrothermal treatment remained unchanged (24 hours) while the $\mathrm{pH}$ of the initial reacting mixture was fixed to different values between 1 and 10. Monitoring the initial $\mathrm{pH}$ of the reacting media quickly led to the quantitative recovery of uranium. Indeed, PERALS analyses undertaken on the supernatants showed that the precipitation yield was close to $100 \%$ for $\mathrm{pH} \geq 1$ (Table 3), even though Rai et al. reported the hydrolysis of $\mathrm{U}(\mathrm{IV})$ only for $\mathrm{pH}>2$ at room temperature ${ }^{40}$. This difference could be explained by the use of hydrothermal conditions, which can lead to the modification of equilibrium constants, and allowed the complete complexation of tetravalent uranium for a lower $\mathrm{pH}$ value.

Table 3. Uranium(IV) precipitation yield measured by PERALS analyses as a function of $\mathrm{pH}\left(\mathrm{T}=250^{\circ} \mathrm{C}, \mathrm{t}=24 \mathrm{~h}\right)$.

\begin{tabular}{cccc}
\hline pH & $\mathbf{n}(\mathbf{U}) \mathbf{i}(\mathbf{m o l})$. & $\mathbf{n}(\mathbf{U})_{\text {sol. }}(\mathbf{m o l})$. & $\begin{array}{c}\text { Uranium(IV) precipitation } \\
\text { yield (\%) }\end{array}$ \\
\hline$<1$ & $4.79 \cdot 10^{-4}$ & $(1.35 \pm 0.03) \times 10^{-4}$ & $71.7 \pm 2.3$ \\
1 & $4.78 \cdot 10^{-4}$ & $(2.27 \pm 0.07) \times 10^{-6}$ & $99.5 \pm 2.9$ \\
2 & $4.79 \cdot 10^{-4}$ & $<$ L.D. & $99.9 \pm 0.2$ \\
4 & $4.79 \cdot 10^{-4}$ & $<$ L.D. & $99.9 \pm 0.2$ \\
5 & $4.78 \cdot 10^{-4}$ & $(1.3 \pm 0.2) \times 10^{-7}$ & $99.9 \pm 12.2^{*}$ \\
6 & $4.78 \cdot 10^{-4}$ & $(6.9 \pm 0.6) \times 10^{-7}$ & $99.9 \pm 9.0^{*}$ \\
8 & $4.78 \cdot 10^{-4}$ & $(3.6 \pm 0.1) \times 10^{-7}$ & $99.9 \pm 3.0$ \\
10 & $4.79 \cdot 10^{-4}$ & $(4.9 \pm 0.1) \times 10^{-6}$ & $99.0 \pm 3.4$ \\
\hline
\end{tabular}

Limit of detection (L.D.) : $1.10^{-8} \mathrm{~mol}$.

*Huge measurement uncertainty due to the very low activity measured in solution.

The samples prepared for $1<\mathrm{pH}<10$ were characterized by PXRD (Figure 7). The powder previously obtained at $250^{\circ} \mathrm{C}$ without any control of the $\mathrm{pH}$ was also reported as a matter of comparison, and further labelled as " $\mathrm{pH}<1$ ". Whatever the initial conditions tested 
in terms of acidity, all the PXRD diagrams collected matched well with a single fluorite-type structure characteristic of $\mathrm{UO}_{2+\mathrm{x}}$ oxides or of $\mathrm{UO}_{2+\mathrm{x}} / \mathrm{U}_{4} \mathrm{O}_{9}$ mixtures ${ }^{35}$. Once again, no XRD lines splitting, that could sign the formation of $\mathrm{U}_{3} \mathrm{O}_{7}$, was observed. Also, bringing the $\mathrm{pH}$ towards high values then did not lead to stabilize $\mathrm{U}(\mathrm{OH})_{4}$, which systematically aged to form uranium oxide. While previous authors only reported samples prepared close to neutral $\mathrm{pH}$ values ${ }^{18-20}$, the hydrothermal conversion of $\mathrm{U}\left(\mathrm{C}_{2} \mathrm{O}_{4}\right)_{2} \cdot \mathrm{nH}_{2} \mathrm{O}$ was then proved to be possible on a wide range of operating conditions.

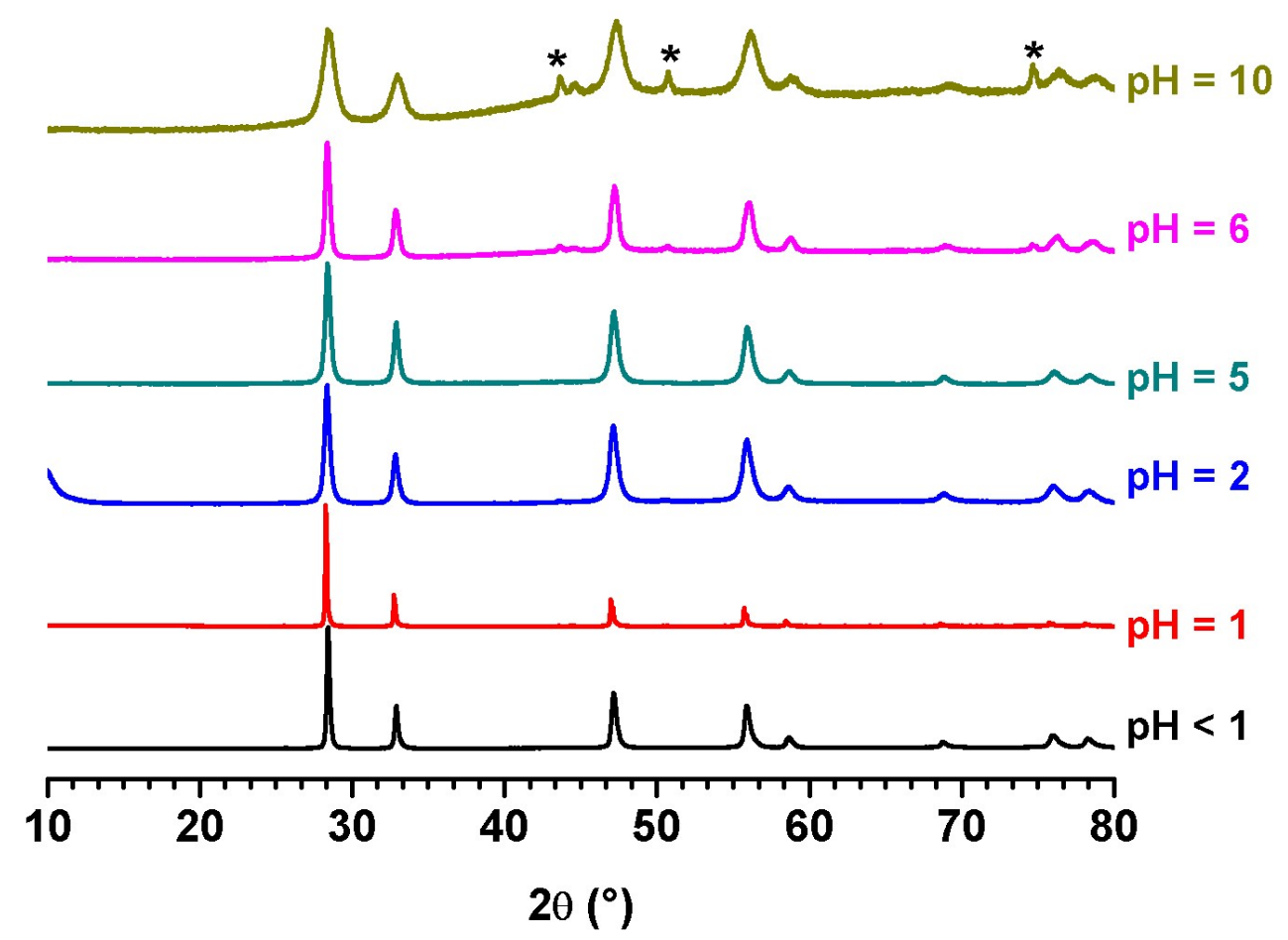

Figure 7. Variation of the PXRD patterns recorded for $\mathrm{UO}_{2+\mathrm{x}} \cdot \mathrm{nH}_{2} \mathrm{O}$ samples prepared by hydrothermal conversion of $\mathrm{U}\left(\mathrm{C}_{2} \mathrm{O}_{4}\right)_{2} \cdot \mathrm{nH}_{2} \mathrm{O}\left(\mathrm{T}=250^{\circ} \mathrm{C}, \mathrm{t}=24 \mathrm{~h}\right)$ as a function of the initial $\mathrm{pH}$ value. $*$ : XRD lines associated to the sample holder.

Although the characteristic XRD lines of the fluorite-type structure were systematically obtained, Rietveld refinements of the PXRD patterns (Figure 8) once again revealed that $\mathrm{pH}$ variation impacted both the unit cell parameters and the average crystallite size. Conversely to what was observed when studying the effect of hydrothermal treatment temperature, the lattice volume mostly remained in the classical range of variation for $\mathrm{UO}_{2+\mathrm{x}}$. For the lowest $\mathrm{pH}$ values investigated (i.e. up to $\mathrm{pH}=1$ ), it was found near the reference value reported for $\mathrm{UO}_{2.00}(\mathrm{~V}=$ $\left.163.781 \AA^{3}\right)^{46}$, therefore indicating that the $\mathrm{O} / \mathrm{U}$ ratio probably remained close to 2 in such 
operating conditions. Increasing the $\mathrm{pH}$ in the initial reacting media led to favor the uranium oxidization, which was illustrated by the decrease of the unit cell volume. This latter first remained constant around $161.3 \AA^{3}$ for $2 \leq \mathrm{pH} \leq 6$, which typically corresponded to $\mathrm{UO}_{2+\mathrm{x}} /$ $\mathrm{U}_{4} \mathrm{O}_{9}$ mixtures with a global $\mathrm{O} / \mathrm{U}$ ratio in the $2.20-2.25$ range based on the data reported in the literature ${ }^{51}$. In basic media (i.e. for $\mathrm{pH}=10$ ), the lattice volume was finally found to be below $161 \AA^{3}$, which might indicate an increase of $\mathrm{O} / \mathrm{U}$ towards higher values, and the presence of $\mathrm{U}(\mathrm{VI})$ in the system, as it was observed when studying the effect of the hydrothermal treatment temperature.

In the same time, a strong decrease of the average crystallites size was noted when raising the $\mathrm{pH}$ of the reacting media. Indeed, samples prepared around $\mathrm{pH}=1$ led to crystallite size between 80 and $110 \mathrm{~nm}$ while this value drastically dropped down to $20-30 \mathrm{~nm}$ for $2 \leq \mathrm{pH}$ $\leq 5$. Such trend could be easily explained by the more rapid uranium(IV) hydrolysis then $\mathrm{U}(\mathrm{OH})_{4}$ precipitation in basic media, which led the crystallites nucleation step to be favored over the growth processes.

a)

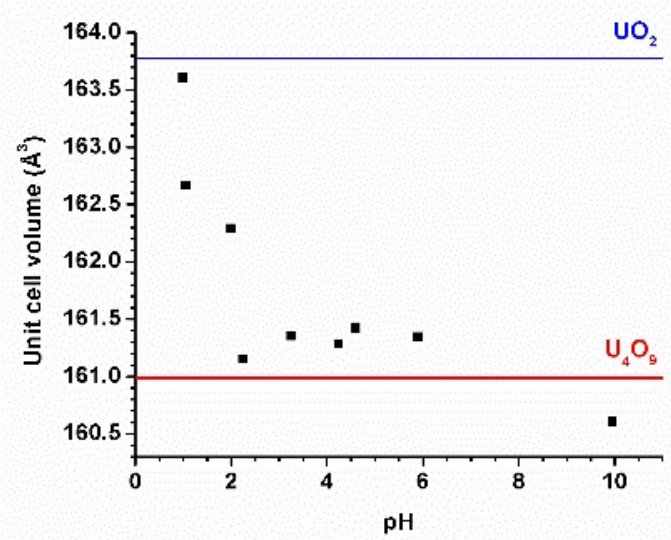

b)

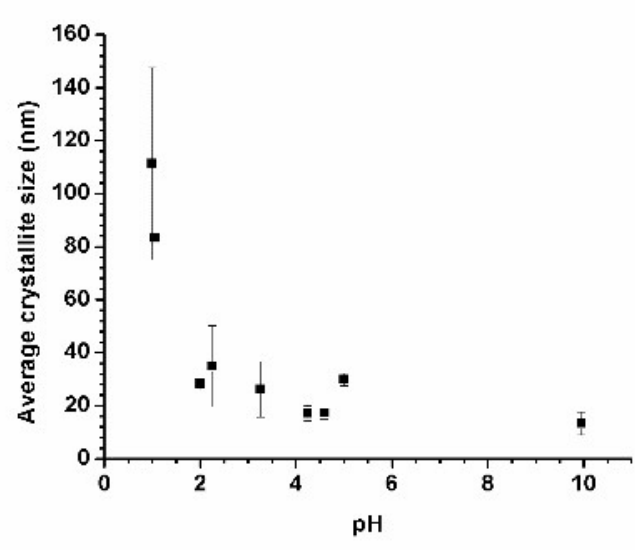

Figure 8. Variation of the unit cell volume (a) and average crystallites size (b) of uranium oxide samples as a function of initial $\mathrm{pH}\left(\mathrm{T}=250^{\circ} \mathrm{C}, \mathrm{t}=24 \mathrm{~h}\right)$. Reference values for $\mathrm{UO}_{2}$ and $\mathrm{U}_{4} \mathrm{O}_{9}$ are taken from references ${ }^{46}$ and ${ }^{45}$, respectively.

SEM observations were further undertaken and revealed important modifications of the morphology as a function of the starting $\mathrm{pH}$ value (Figure 9). At $\mathrm{pH}=1$, the powders exhibited the morphology already described when working in uncontrolled acidic media, made of submicrometric aggregates of elementary crystallites, even if they appeared to be more faceted. For $\mathrm{pH} \geq 2$, the samples appeared to be systematically composed of microspheres exhibiting heterogeneous size distribution. Such a morphology was already reported for similar $\mathrm{pH}$ values 
after the hydrothermal conversion of uranium(IV) aspartate ${ }^{14}$. This clearly underlined the crucial role played by the $\mathrm{pH}$ in the design of morphology-controlled uranium oxides prepared through wet chemistry methods in hydrothermal conditions. The spherical morphology of the powders was further maintained up to $\mathrm{pH}=5$, although isolated crystallites became more and more visible. Finally, for the higher $\mathrm{pH}$ values (typically between 6 and 10), the powders were found to be mostly composed of elementary nanoscale crystallites. This observation clearly confirms the rapid hydrolysis of uranium (IV) in basic media, which prevented further growth of the particles and hindered aggregation phenomena. Consequently, the powder was found to exhibit a morphology close to that already described by Martinez et al. for uranium dioxide samples prepared through direct hydroxide precipitation ${ }^{39}$.
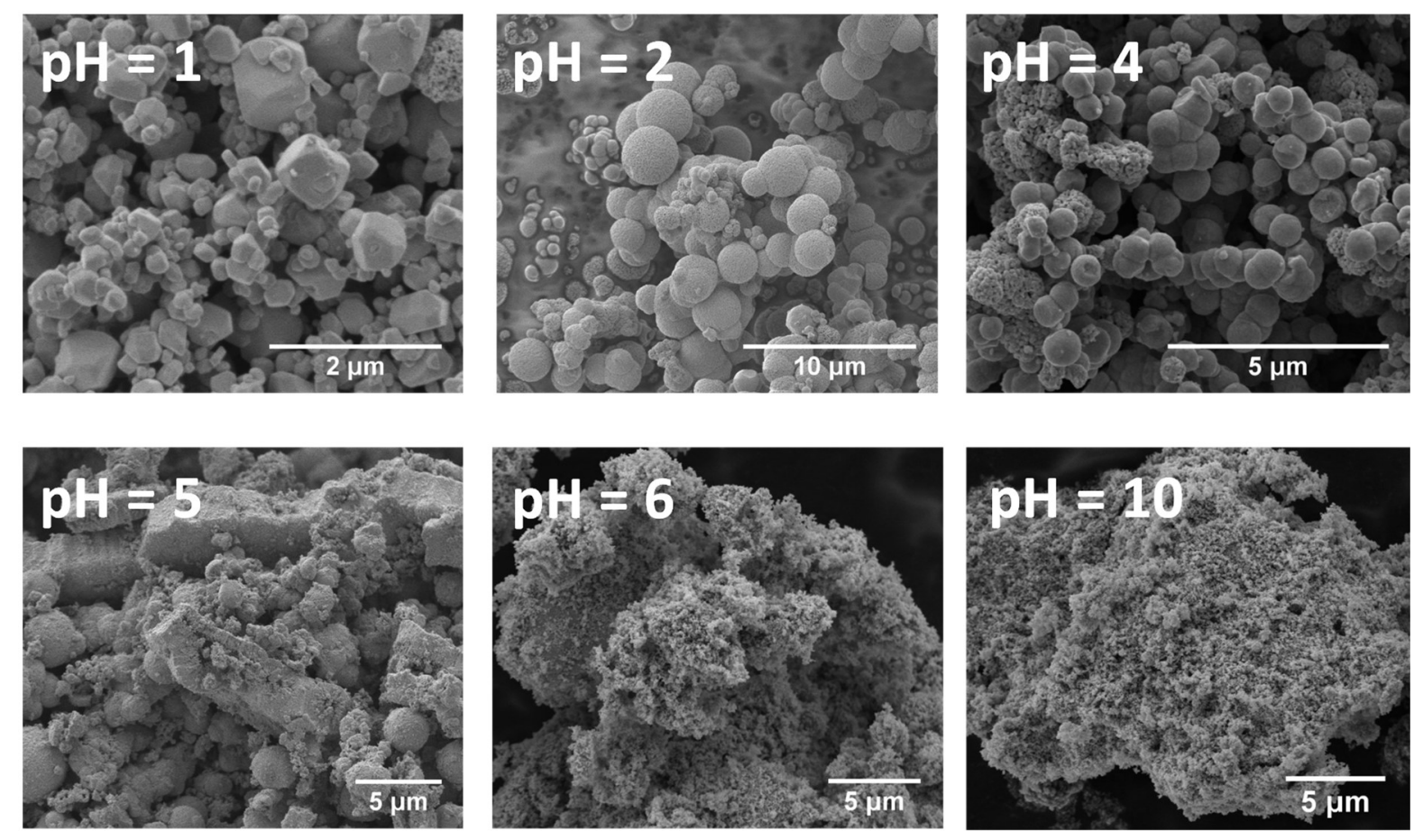

Figure 9. SEM images recorded for samples prepared by hydrothermal conversion of $\mathrm{U}\left(\mathrm{C}_{2} \mathrm{O}_{4}\right)_{2} \cdot \mathrm{nH}_{2} \mathrm{O}\left(\mathrm{T}=250^{\circ} \mathrm{C}, \mathrm{t}=24 \mathrm{~h}\right)$ at various $\mathrm{pH}$.

Finally, the carbon content and hydration rate of the samples were followed by TGA and carbon analyzer. Whatever the conditions considered, the powders only contained limited amounts of impurities (Table 4), although it was found to increase with $\mathrm{pH}$. Indeed, whereas very acidic conditions (i.e. for $\mathrm{pH} \leq 1$ ) led to carbon amounts close to $100 \mathrm{ppm}$, it was found to be one order of magnitude higher between $\mathrm{pH}=2$ and 10. On this basis, it is probable that the increase of the precipitation kinetics with the $\mathrm{pH}$ favored the carbon trapping within the structure, and/or between the crystallites forming the aggregates. Another explanation could be 
linked to the presence of carbonate ions in solution following the degradation of oxalate entities. Indeed, regarding to their speciation between $\mathrm{pH}=3$ and $\mathrm{pH}=6, \mathrm{HCO}_{3}{ }^{-}$groups could partially substitute $\mathrm{OH}^{-}$ions during the precipitation process. Nevertheless, it is important to mention that the carbon amounts measured remained once again close to that obtained after heat treatment of oxalates ${ }^{9}$, and far lower than those measured in $\mathrm{UO}_{2}$ microspheres prepared through wet chemistry processes, which can reach up to 3 wt. $\%{ }^{14,15}$. On the other hand, the water content remained almost constant up to $\mathrm{pH}=6$ and reached about $0.1-0.2 \mathrm{H}_{2} \mathrm{O}$ per formula unit. Keeping in mind that the associated weight loss could be also linked with a partial reduction of uranium, the samples can then be considered as nearly anhydrous. Nevertheless, a strong increase was noted for $\mathrm{pH} \geq 8$, where the hydration rate progressively rose up to one mole of $\mathrm{H}_{2} \mathrm{O}$ per mole of uranium. Although this value was still in good agreement with a precipitation mechanism based on the hydrolysis of U(IV), it showed that basic conditions led to slow down the dehydration of the final compound. Also, owing to the high value suspected for the $\mathrm{O} / \mathrm{U}$ ratio in this $\mathrm{pH}$ range, one cannot exclude the formation of amorphous uranium(VI) oxo-hydroxides such as schoepite ${ }^{59}$ in our system, even if they were not evidenced though XRD.

Table 4. Carbon and water contents determined in the samples prepared by hydrothermal conversion of $\mathrm{U}\left(\mathrm{C}_{2} \mathrm{O}_{4}\right)_{2} \cdot \mathrm{nH}_{2} \mathrm{O}\left(\mathrm{T}=250^{\circ} \mathrm{C}, \mathrm{t}=24 \mathrm{~h}\right)$ for various starting $\mathrm{pH}$ values.

\begin{tabular}{ccccc}
\hline pH & $\begin{array}{c}\text { Total weight } \\
\text { loss at } \mathbf{1 0 0 0}^{\circ} \mathbf{C}(\%)\end{array}$ & $\mathbf{C}($ wt.\%) & $\mathbf{H}_{2} \mathbf{O}($ wt.\%) & $\begin{array}{c}\mathrm{H}_{2} \mathrm{O} \\
\text { (mol. per unit formula) }\end{array}$ \\
\hline$<1$ & $0.80 \pm 0.05$ & $<0.01$ & $0.80 \pm 0.05$ & $0.12 \pm 0.01$ \\
1 & $<0.10$ & $<0.01$ & $<0.01$ & $<0.01$ \\
2 & $1.20 \pm 0.05$ & $0.09 \pm 0.02$ & $1.11 \pm 0.05$ & $0.17 \pm 0.01$ \\
5 & $1.60 \pm 0.05$ & $0.10 \pm 0.02$ & $1.50 \pm 0.05$ & $0.23 \pm 0.01$ \\
6 & $1.55 \pm 0.05$ & $0.32 \pm 0.02$ & $1.23 \pm 0.05$ & $0.19 \pm 0.01$ \\
8 & $2.51 \pm 0.05$ & $0.07 \pm 0.02$ & $2.44 \pm 0.05$ & $0.38 \pm 0.01$ \\
10 & $5.90 \pm 0.05$ & $0.08 \pm 0.02$ & $5.82 \pm 0.05$ & $0.93 \pm 0.01$ \\
\hline
\end{tabular}

\subsection{Effect of hydrothermal treatment duration}

Finally, the last set of experiments was dedicated to the impact of kinetics on the physico-chemical properties of the uranium oxide samples resulting from hydrothermal conversion of $\mathrm{U}\left(\mathrm{C}_{2} \mathrm{O}_{4}\right)_{2} \cdot \mathrm{nH}_{2} \mathrm{O}$. With this objective, the heat treatment was maintained at $250^{\circ} \mathrm{C}$ while an initial $\mathrm{pH}$ value of 5 was chosen in order to guarantee the quantitative precipitation of 
uranium. Such conditions were also found to yield hyper-stoichiometric oxide samples (typically with $2.20 \leq \mathrm{O} / \mathrm{U} \leq 2.25$ ) containing measurable amounts of carbon and water. In order to monitor the evolution of impurities contents as well as the $\mathrm{O} / \mathrm{U}$ ratio, the hydrothermal conversion process was achieved with durations varying from 1 to $48 \mathrm{~h}$.

For all the conditions tested, the obtained powders were found to be crystalline and exhibited XRD lines compatible with the formation of $\mathrm{UO}_{2+\mathrm{x}}$ oxides or of $\mathrm{UO}_{2+\mathrm{x}} / \mathrm{U}_{4} \mathrm{O}_{9}$ mixtures (Figure 10). Also, no additional signal, such as that of residual $\mathrm{U}\left(\mathrm{C}_{2} \mathrm{O}_{4}\right)_{2} \cdot \mathrm{nH}_{2} \mathrm{O}$ was observed, which evidenced its full and rapid conversion in such operating conditions. This agreed well with the data published by Crossey ${ }^{38}$. Indeed, assuming that the activation energy reported in this study $\left(\mathrm{E}_{\mathrm{A}}=207 \mathrm{~kJ} \cdot \mathrm{mol}^{-1}\right)$ remained constant up to $250^{\circ} \mathrm{C}$, one can determine the kinetic constant associated to the oxalate decomposition, supposed to be a first-order reaction. Such calculations yield a reaction half-time of about 1.5 minutes at $\mathrm{pH}=5$. On this basis, the decomposition was considered to be complete after 10 periods, i.e. 15 minutes, which corresponds to the conversion of $99.9 \%$ of the reactants. In good agreement with these calculations, the uranium precipitation yield was found to be almost complete after one hour of hydrothermal treatment (Table 5).

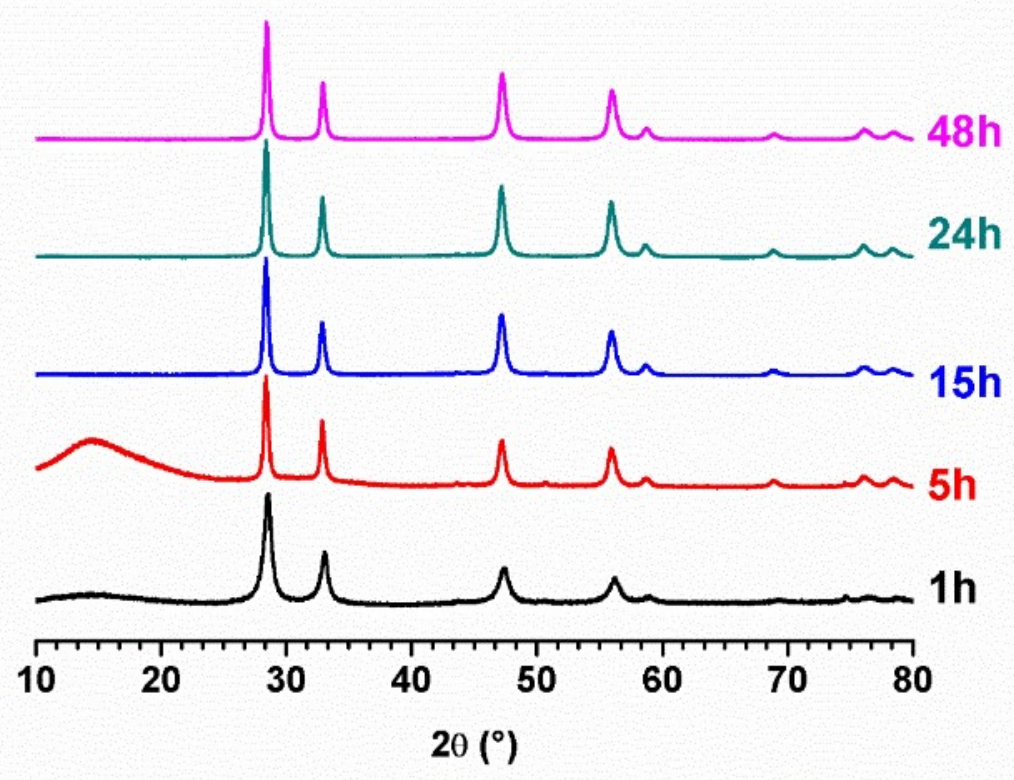

Figure 10. Evolution of the PXRD patterns obtained for samples prepared by hydrothermal conversion of $\mathrm{U}\left(\mathrm{C}_{2} \mathrm{O}_{4}\right)_{2} \cdot \mathrm{nH}_{2} \mathrm{O}\left(\mathrm{T}=250^{\circ} \mathrm{C}, \mathrm{pH}=5\right)$. 
Table 5. Uranium(IV) precipitation yield measured by PERALS analyses as a function of the heat duration $\left(\mathrm{T}=250^{\circ} \mathrm{C}, \mathrm{pH}=5\right)$.

\begin{tabular}{cccc}
\hline Time (hours) & $\mathbf{n}(\mathbf{U}) \mathbf{i}(\mathbf{m o l})$. & $\mathbf{n}(\mathbf{U})$ sol. (mol.) & $\begin{array}{c}\text { Uranium(IV) } \\
\text { precipitation yield (\%) }\end{array}$ \\
\hline 1 & $4.79 \times 10^{-4}$ & $(1.20 \pm 0.01) \times 10^{-5}$ & $97.5 \pm 0.4$ \\
5 & $4.78 \times 10^{-4}$ & $(2.20 \pm 0.06) \times 10^{-7}$ & $99.9 \pm 2.9$ \\
15 & $4.78 \times 10^{-4}$ & $(4.7 \pm 0.2) \times 10^{-7}$ & $99.9 \pm 3.9$ \\
24 & $4.79 \times 10^{-4}$ & $(1.3 \pm 0.2) \times 10^{-7}$ & $99.9 \pm 12.1$ \\
\hline
\end{tabular}

Even though the quantitative precipitation of uranium was reached very rapidly, Rietveld refinements of the PXRD patterns (Figure 11) revealed that 5 hours of heat treatment were required to reach a plateau in terms of lattice parameters and average crystallite size. Indeed, after only one hour of heat treatment, the unit cell volume was found to $160.8 \AA^{3}$, which accounted for a strongly oxidized system regarding to $\mathrm{UO}_{2}$. For longer hydrothermal treatment durations, the unit cell volume then increased to reach a constant value of about $162.0 \AA^{3}$, which fitted well with the usual range of variation of $\mathrm{UO}_{2+\mathrm{x}} / \mathrm{U}_{4} \mathrm{O}_{9}$ lattice parameters.

A similar evolution was observed for the crystallite size. It was found that the powders precipitated after only 1 hour of hydrothermal treatment were composed by small crystallites of less than $10 \mathrm{~nm}$, which was only 2 to 3 times higher than that reported by Martinez et al. for uranium oxides prepared by direct precipitation of uranium hydroxide at room temperature. Rather than oxalate decomposition, the aging and growth of $\mathrm{U}(\mathrm{OH})_{4}$ nuclei then could be considered as the main limitation to the preparation of well-crystallized $\mathrm{UO}_{2+\mathrm{x}} \cdot \mathrm{nH}_{2} \mathrm{O}$ powders on such a short time. Conversely, the samples prepared after 5 to 48 hours of heating treatment presented larger crystallite size (i.e. up to $30-40 \mathrm{~nm}$ ). 
a)

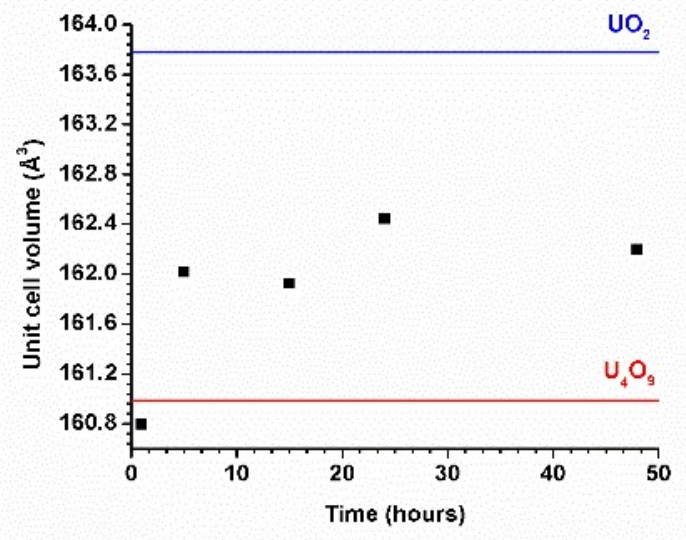

b)

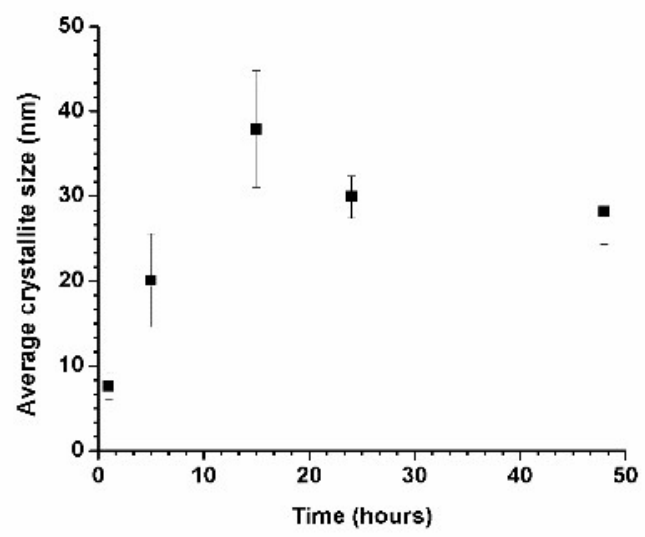

Figure 11. Evolution of the unit cell volume (a) and average crystallites size (b) of $\mathrm{UO}_{2+\mathrm{x}} \cdot \mathrm{nH}_{2} \mathrm{O}$ samples during the hydrothermal conversion of $\mathrm{U}\left(\mathrm{C}_{2} \mathrm{O}_{4}\right)_{2} \cdot \mathrm{nH}_{2} \mathrm{O}$ $\left(\mathrm{T}=250^{\circ} \mathrm{C}, \mathrm{pH}=5\right)$. Reference values for $\mathrm{UO}_{2}$ and $\mathrm{U}_{4} \mathrm{O}_{9}$ are taken from references ${ }^{46}$ and ${ }^{45}$, respectively.

The accurate stoichiometry of the samples prepared after 1 and 5 hours of hydrothermal conversion $\left(\mathrm{T}=250^{\circ} \mathrm{C}, \mathrm{pH}=5\right)$ was then further checked through HERFD-XANES (Figure 12). The two samples investigated presented very different spectra. Indeed, after 1 hour of conversion, 4 peaks were clearly visible on the spectrum at 3725.5, 3726.9, 3728.8 and 3732.4 $\mathrm{eV}$. They attested the presence of both U(IV), U(V) and U(VI) in the sample, including uranyl groups. As the coexistence of all these uranium species is not possible in a single phase, the formation of a polyphase sample can be suggested. Conversely, only 2 main contributions were recorded for the sample prepared after 5 hours of heating, meaning that the U(VI) amount drastically decreased in the system, which was then mainly composed of U(IV) and U(V).

In order to go further, the $\mathrm{O} / \mathrm{U}$ ratio in each sample was quantified through a linear combination fitting coupled to the normalization of the uranium amount inside the references used (i.e. $\mathrm{UO}_{2}, \mathrm{U}_{4} \mathrm{O}_{9}, \mathrm{U}_{3} \mathrm{O}_{8}$ and $\left.\mathrm{UO}_{2}\left(\mathrm{NO}_{3}\right)_{2} \cdot \mathrm{nH}_{2} \mathrm{O}\right)$. The results presented in Table 6 confirmed that the sample prepared after only 1 hour of heat treatment was strongly oxidized with $\mathrm{O} / \mathrm{U}=$ $2.65 \pm 0.14$ corresponding to an average uranium oxidation state equal to +5.3 . As already suggested, this sample then probably corresponds to a mixture composed by a crystalline $\mathrm{UO}_{2+\mathrm{x}} / \mathrm{U}_{4} \mathrm{O}_{9}$ phase (evidenced by XRD) and an amorphous $\mathrm{U}(\mathrm{VI})$-residue. The $\mathrm{O} / \mathrm{U}$ ratio was further found to decrease after 5 hours of hydrothermal conversion down to $2.45 \pm 0.06\left(\mathrm{U}^{+4.9}\right)$. One can note that these values remained significantly higher than that determined for heat treatment of 24 hours in more acidic conditions $(\mathrm{pH}<1: \mathrm{O} / \mathrm{U}=2.13 \pm 0.04)$. 


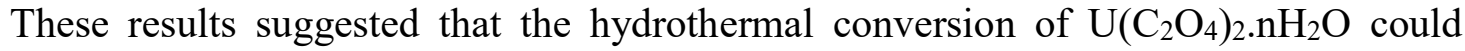
proceed in two distinct steps. The first one would correspond to the oxidative decomposition/dissolution of the oxalate initially precipitated when mixing oxalic acid and U(IV) hydrochloric solution. The oxide formation could then be achieved through the progressive reduction of uranium in hydrothermal conditions, thanks to the organic moieties generated in solution by the decomposition of oxalates. Indeed, such mechanism was reported for long in geologic media, where uranyl ions were precipitated as $\mathrm{UO}_{2}$ in late diagenetic conditions $\left(\mathrm{T}=100-200^{\circ} \mathrm{C}\right)$ by interacting with simple organic matter ${ }^{60,61}$. Such a dissolution/precipitation process would explain both the initial formation of a mixture composed by a crystalline $\mathrm{U}(\mathrm{IV}) / \mathrm{U}(\mathrm{V})$ phase and a U(VI) amorphous residue, then the progressive reduction of the oxide sample with time, but also the drastic modification of the samples morphology compared to the starting square platelets.

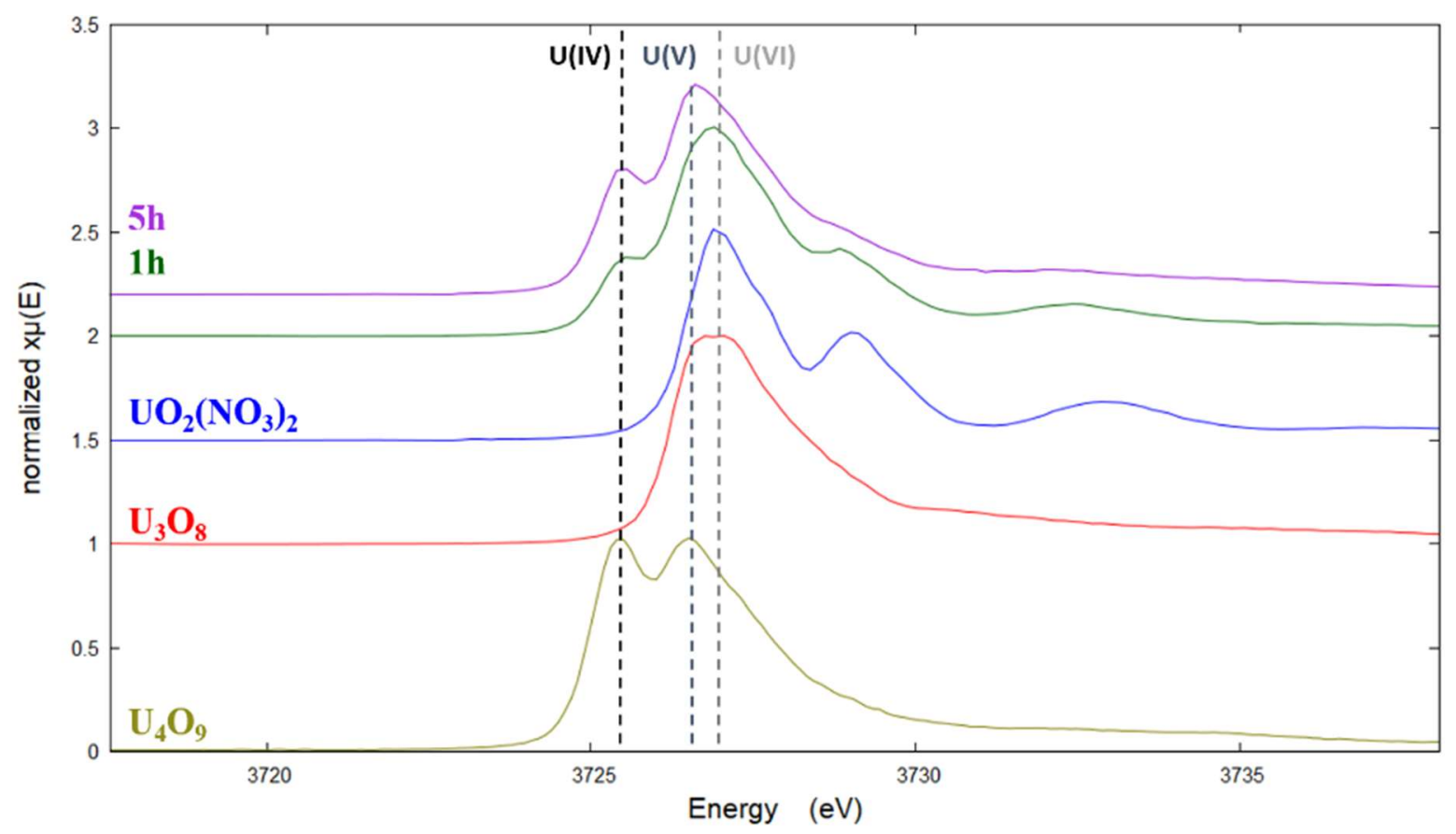

Figure 12. Normalized HERFD-XANES spectra of reference samples and of oxide samples obtained after hydrothermal treatment of $\mathrm{U}\left(\mathrm{C}_{2} \mathrm{O}_{4}\right)_{2} \cdot \mathrm{nH}_{2} \mathrm{O}$ at $250^{\circ} \mathrm{C}$ and $\mathrm{pH}=5$ for various durations. 
Table 6. Uranium oxidation state distribution obtained from the linear combination fitting of HERFD-XANES spectra.

\begin{tabular}{cccccc}
\hline Holding time (h) & U(IV) (\%) & U(V) (\%) & U(VI) (\%) & O/U ratio & $\begin{array}{c}\text { Average U } \\
\text { oxidation state }\end{array}$ \\
\hline 1 & $14.9 \pm 0.3$ & $39.6 \pm 1.6$ & $45.5 \pm 3.1$ & $2.65 \pm 0.14$ & 5.3 \\
5 & $26.5 \pm 0.3$ & $57.8 \pm 1.6$ & $15.7 \pm 0.6$ & $2.45 \pm 0.06$ & 4.9 \\
\hline
\end{tabular}

The peculiar behavior of the sample prepared after only 1 hour of hydrothermal treatment was also confirmed during the determination of carbon and water contents (Table 7). Indeed, the residual carbon amount was found to be close to $10000 \mathrm{ppm}$, which was by far the highest value measured during this study. Nevertheless, it dropped down to 500-1000 ppm when extending the hydrothermal treatment to $5-48$ hours. The organic species coming from the initial decomposition of oxalate groups, which played an important role in uranium reduction, were then probably trapped during the formation of the first oxide nuclei, then were quickly and efficiently eliminated throughout the hydrothermal treatment. Simultaneously, the water content also decreased, going from about $0.7 \mathrm{H}_{2} \mathrm{O}$ per formula unit after 1 hour to 0.1 0.2 after 5 to 48 hours. Along with the carbon elimination, the crystallization of uranium oxide was then also accompanied by the partial dehydration of the samples.

Table 7. Carbon and water contents determined in the samples prepared by hydrothermal conversion of $\mathrm{U}\left(\mathrm{C}_{2} \mathrm{O}_{4}\right)_{2} \cdot \mathrm{nH}_{2} \mathrm{O}\left(\mathrm{T}=250^{\circ} \mathrm{C}, \mathrm{pH}=5\right)$ for various holding times.

\begin{tabular}{|c|c|c|c|c|}
\hline $\begin{array}{l}\text { Holding time } \\
\text { (hours) }\end{array}$ & $\begin{array}{c}\text { Total weight } \\
\text { loss at } 1000^{\circ} \mathrm{C}(\%)\end{array}$ & C (wt.\%) & $\mathrm{H}_{2} \mathrm{O}($ wt.\%) & $\begin{array}{c}\mathrm{H}_{2} \mathrm{O} \\
\text { (mol. per unit formula) }\end{array}$ \\
\hline 1 & $5.00 \pm 0.05$ & $0.91 \pm 0.01$ & $4.09 \pm 0.05$ & $0.65 \pm 0.01$ \\
\hline 5 & $1.40 \pm 0.05$ & $0.07 \pm 0.02$ & $1.33 \pm 0.05$ & $0.20 \pm 0.01$ \\
\hline 15 & $1.00 \pm 0.05$ & $0.05 \pm 0.02$ & $0.95 \pm 0.05$ & $0.14 \pm 0.01$ \\
\hline 24 & $1.60 \pm 0.05$ & $0.10 \pm 0.02$ & $1.50 \pm 0.05$ & $0.23 \pm 0.01$ \\
\hline 48 & $1.00 \pm 0.05$ & $0.10 \pm 0.02$ & $0.90 \pm 0.05$ & $0.14 \pm 0.01$ \\
\hline
\end{tabular}




\section{Conclusion}

Mixtures of uranium oxides, with a typical $\mathrm{O} / \mathrm{U}$ ratio ranging from 2.12 to 2.65 , were obtained by hydrothermal conversion of $\mathrm{U}\left(\mathrm{C}_{2} \mathrm{O}_{4}\right)_{2} \cdot \mathrm{nH}_{2} \mathrm{O}$ in various operating conditions. In very acidic media (i.e. for $\mathrm{pH} \leq 1$ ), the lowest temperatures explored (typically from 180 to $200^{\circ} \mathrm{C}$ ) led to $\mathrm{O} / \mathrm{U}$ ratio of $2.38 \pm 0.10$ while the XRD pattern did not present any characteristic reflections of $\mathrm{U}_{3} \mathrm{O}_{7}$ or $\mathrm{U}_{3} \mathrm{O}_{8}$. A similar diffraction diagram, typical for $\mathrm{UO}_{2+\mathrm{x}}$ or $\mathrm{UO}_{2+\mathrm{x}} / \mathrm{U}_{4} \mathrm{O}_{9}$ mixtures was further obtained for samples prepared between 220 and $250^{\circ} \mathrm{C}$, while $\mathrm{O} / \mathrm{U}$ was lowered to $2.13 \pm 0.04$. The use of hydrothermal conditions, combined with the nanocrystalline nature of the powders then allowed to stabilize mixtures of cubic uranium oxide phases, which cannot be uniquely distinguished from XRD alone, while XANES results indicated an important $\mathrm{U}(\mathrm{V})$ contribution in some powders. In parallel, increasing the temperature of the hydrothermal treatment efficiently improved the elimination of residual carbon species. Typical amounts of about 100-200 ppm were measured in the samples, which was of the same order of magnitude than the values usually observed when performing thermal conversion of An(IV) oxalates in air. Additionally, high temperature of hydrothermal treatment was also found to yield almost anhydrous samples.

Hydrothermal conversion of $\mathrm{U}\left(\mathrm{C}_{2} \mathrm{O}_{4}\right)_{2} \cdot \mathrm{nH}_{2} \mathrm{O}$ also led to the drastic modification of the powders morphology. With this aim, $\mathrm{pH}$ monitoring could be used to shift from bipyramidal aggregates (up to $\mathrm{pH}=1)$, microspheres $(2 \leq \mathrm{pH} \leq 5)$ and finally to nanometric powders $(\mathrm{pH}>$ 5). However, the increase of the kinetics of $\mathrm{U}^{4+}$ hydrolysis with the $\mathrm{pH}$ value led to enhance the amount of carbon trapped in the samples, even if this latter remained of the same order of magnitude than that reported for uranium(IV) oxalate heated under reducing atmosphere.

Finally, kinetics of the hydrothermal conversion suggested a two-step mechanism for the transformation of uranium(IV) oxalate into oxide. Indeed, if the complete decomposition of the initial oxalate was achieved in only few hours, the $\mathrm{O} / \mathrm{U}$ ratio in the samples appeared to be strongly impacted by the duration of the hydrothermal treatment. After 1 hour, it suggested the existence of a U(VI)-bearing secondary phase, such as amorphous $\mathrm{UO}_{3}$, aside the crystalline $\mathrm{UO}_{2+\mathrm{x}} / \mathrm{U}_{4} \mathrm{O}_{9}$ mixture, which further tended to reduce to $\mathrm{UO}_{2+\mathrm{x}}$. The hydrothermal conversion is then likely to be composed of an oxidative dissolution of the initial precursor, followed by the in situ reduction of $\mathrm{U}(\mathrm{V})$ and/or $\mathrm{U}(\mathrm{VI})$ in solution thanks to organic species and the final hydrolysis process leading to the oxide sample.

By these means, hydrothermal conversion appeared as an easy and efficient way to yield highly pure uranium oxide samples in solution. The absence of impurities as well as the 
possibility to monitor the samples morphology also paves the way to the direct sintering of the powders prepared. Avoiding the thermal conversion of oxalate will then give the opportunity to set up dustless processes that will lead from ions in solution to sintered pellets in a limited number of steps.

\section{Acknowledgements}

Authors are grateful to J. Lautru for his help during SEM observations. They would also like to thank the Materials Federative Project included in the NEEDS program (Nucléaire, Energie, Environnement, Déchets, Société) of CNRS for its continuous financial support. This study received funding from the GENIORS project (H2020 Euratom Research and Innovation Programme under grant agreement $n^{\circ} 755171$ ). We are also grateful to SOLEIL synchrotron for providing beamtime.

\section{References}

1. Kelly, J. E.: Generation IV International Forum: A decade of progress through international cooperation, Prog Nucl Energ 2014, 77, 240-246.

2. Talip, Z.; Peuget, S.; Magnin, M.; Tribet, M.; Valot, C.; Vauchy, R.; Jegou, C.: Characterization of un-irradiated MIMAS MOX fuel by Raman spectroscopy and EPMA, J Nucl Mater 2018, 499, 88-97.

3. Oudinet, G.; Munoz-Viallard, I.; Aufore, L.; Gotta, M. J.; Becker, J. M.; Chlarelli, G.; Castelli, R.: Characterization of plutonium distribution in MIMAS MOX by image analysis, J Nucl Mater 2008, 375, 86-94.

4. Abraham, F.; Arab-Chapelet, B.; Rivenet, M.; Tamain, C.; Grandjean, S.: Actinide oxalates, solid state structures and applications, Coord. Chem. Rev. 2014, 266-267, 28-68.

5. Grandjean, S.; Arab-Chapelet, B.; Robisson, A. C.; Abraham, F.; Martin, P.; Dancausse, J. P.; Herlet, N.; Leorier, C.: Structure of mixed U(IV)-An(III) precursors synthesized by coconversion methods (where $\mathrm{An}=\mathrm{Pu}, \mathrm{Am}$ or Cm), J Nucl Mater 2009, 385, 204-207.

6. Tamain, C.; Chapelet, B. A.; Rivenet, M.; Abraham, F.; Caraballo, R.; Grandjean, S.: Crystal Growth and First Crystallographic Characterization of Mixed Uranium(IV)Plutonium(III) Oxalates, Inorg Chem 2013, 52, 4941-4949.

7. Dollimore, D.: The Thermal-Decomposition of Oxalates - a Review, Thermochim Acta 1987, 117, 331-363.

8. Vigier, N.; Grandjean, S.; Arab-Chapelet, B.; Abraham, F.: Reaction mechanisms of the thermal conversion of $\mathrm{Pu}(\mathrm{IV})$ oxalate into plutonium oxide, $J$ Alloy Compd 2007, 444, 594597.

9. Martinez, J.; Clavier, N.; Ducasse, T.; Mesbah, A.; Audubert, F.; Corso, B.; Vigier, N.; Dacheux, N.: From uranium(IV) oxalate to sintered $\mathrm{UO}_{2}$ : Consequences of the powders' thermal history on the microstructure, J Eur Ceram Soc 2015, 35, 4535-4546. 
10. White, G. D.; Bray, L. A.; Hart, P. E.: Optimization of Thorium Oxalate Precipitation Conditions Relative to Derived Oxide Sinterability, J Nucl Mater 1981, 96, 305-313.

11. Asakura, K.; Takeuchi, K.: Effect of residual carbon on the sintering behavior of MOX pellets, J Nucl Mater 2006, 348, 165-173.

12. Chambon, C.; Vaudez, S.; Heintz, J. M.: De-densification mechanisms of yttria-doped cerium oxide during sintering in a reducing atmosphere, J. Amer. Ceram. Soc. 2018.

13. Neck, V.; Kim, J. I.: Solubility and hydrolysis of tetravalent actinides, Radiochim Acta 2001, 89, 1-16.

14. Trillaud, V.; Maynadie, J.; Manaud, J.; Hidalgo, J.; Meyer, D.; Podor, R.; Dacheux, N.; Clavier, N.: Synthesis of size-controlled $\mathrm{UO}_{2}$ microspheres from the hydrothermal conversion of U(IV) aspartate, Crystengcomm 2018, 20, 7749-7760.

15. Nkou Bouala, G. I.; Clavier, N.; Podor, R.; Cambedouzou, J.; Mesbah, A.; Brau, H. P.; Léchelle, J.; Dacheux, N.: Preparation and characterisation of uranium oxides with spherical shapes and hierarchical structures, Crystengcomm 2014, 16, 6944-6954.

16. Wang, L.; Zhao, R.; Wang, C. Z.; Yuan, L. Y.; Gu, Z. J.; Xiao, C. L.; Wang, S. A.; Wang, X. W.; Zhao, Y. L.; Chai, Z. F.; Shi, W. Q.: Template-Free Synthesis and Mechanistic Study of Porous Three-Dimensional Hierarchical Uranium-Containing and Uranium Oxide Microspheres, Chem-Eur J 2014, 20, 12655-12662.

17. Zhao, R.; Wang, L.; Gu, Z. J.; Yuan, L. Y.; Xiao, C. L.; Zhao, Y. L.; Chai, Z. F.; Shi, W. Q.: A facile additive-free method for tunable fabrication of $\mathrm{UO}_{2}$ and $\mathrm{U}_{3} \mathrm{O}_{8}$ nanoparticles in aqueous solution, Crystengcomm 2014, 16, 2645-2651.

18. Popa, K.; Walter, O.; Blanco, O. D.; Guiot, A.; Bouexiere, D.; Colle, J. Y.; Martel, L.; Naji, M.; Manara, D.: A low-temperature synthesis method for $\mathrm{AnO}_{2}$ nanocrystals $(\mathrm{An}=\mathrm{Th}, \mathrm{U}$, $\mathrm{Np}$, and $\mathrm{Pu}$ ) and associate solid solutions, Crystengcomm 2018, 20, 4614-4622.

19. Balice, L.; Bouexiere, D.; Cologna, M.; Cambriani, A.; Vigier, J. F.; De Bona, E.; Soraru, G. D.; Kubel, C.; Walter, O.; Popa, K.: Nano and micro $\mathrm{U}_{1-\mathrm{x}} \mathrm{Th}_{\mathrm{x}} \mathrm{O}_{2}$ solid solutions: From powders to pellets, $J$ Nucl Mater 2018, 498, 307-313.

20. Walter, O.; Popa, K.; Blanco, O. D.: Hydrothermal decomposition of actinide(IV) oxalates: a new aqueous route towards reactive actinide oxide nanocrystals, Open Chem 2016, 14, 170-174.

21. Dacheux, N.; Brandel, V.; Genet, M.: Synthesis and Properties of Uranium Chloride Phosphate Tetrahydrate - UClPO $4.4 \mathrm{H}_{2} \mathrm{O}$, New J Chem 1995, 19, 1029-1036.

22. Rabenau, A.: The Role of Hydrothermal Synthesis in Preparative Chemistry, Angew Chem Int Edit 1985, 24, 1026-1040.

23. Dacheux, N.; Aupiais, J.: Determination of uranium, thorium, plutonium, americium, and curium ultratraces by photon electron rejecting alpha liquid scintillation, Anal Chem 1997, 69, 2275-2282.

24. Thompson, P.; Cox, D. E.; Hastings, J. B.: Rietveld Refinement of Debye-Scherrer Synchrotron X-Ray Data from $\mathrm{Al}_{2} \mathrm{O}_{3}, J$ Appl Crystallogr 1987, 20, 79-83.

25. Frontera, C.; Rodriguez-Carvajal, J.: FullProf as a new tool for flipping ratio analysis, Physica B: Condensed Matter 2003, 335, 219-222.

26. Sitaud, B.; Solari, P. L.; Schlutig, S.; Llorens, I.; Hermange, H.: Characterization of radioactive materials using the MARS beamline at the synchrotron SOLEIL, J Nucl Mater 2012, 425, 238-243.

27. LLorens, I.; Solari, P. L.; Sitaud, B.; Bes, R.; Cammelli, S.; Hermange, H.; Othmane, G.; Safi, S.; Moisy, P.; Wahu, S.; Bresson, C.; Schlegel, M. L.; Menut, D.; Bechade, J. L.; Martin, P.; Hazemann, J. L.; Proux, O.; Den Auwer, C.: X-ray absorption spectroscopy 
investigations on radioactive matter using MARS beamline at SOLEIL synchrotron, Radiochim Acta 2014, 102, 957-972.

28. Kvashnina, K. O.; Butorin, S. M.; Martin, P.; Glatzel, P.: Chemical State of Complex Uranium Oxides, Phys Rev Lett 2013, 111.

29. Desgranges, L.; Badinozzi, G.; Simeone, D.; Fischer, H. E.: Refinement of the $\alpha-\mathrm{U}_{4} \mathrm{O}_{9}$ Crystalline Structure: New Insight into the $\mathrm{U}_{4} \mathrm{O}_{9} \rightarrow \mathrm{U}_{3} \mathrm{O}_{8}$ Transformation, Inorg Chem 2011, 50, 6146-6151.

30. Clavier, N.; Hingant, N.; Rivenet, M.; Obbade, S.; Dacheux, N.; Barre, N.; Abraham, F.: $\mathrm{X}$-Ray Diffraction and $\mu$-Raman Investigation of the Monoclinic-Orthorhombic Phase Transition in $\mathrm{Th}_{1-\mathrm{x}} \mathrm{U}_{\mathrm{x}}\left(\mathrm{C}_{2} \mathrm{O}_{4}\right)_{2}$. 2 $\mathrm{H}_{2} \mathrm{O}$ Solid Solutions, Inorg Chem 2010, 49, 1921-1931.

31. Duvieubourg-Garela, L.; Vigier, N.; Abraham, F.; Grandjean, S.: Adaptable coordination of U(IV) in the 2D- $(4,4)$ uranium oxalate network: From 8 to 10 coordinations in the uranium (IV) oxalate hydrates, J Solid State Chem 2008, 181, 1899-1908.

32. Wendlandt, W. W.; George, T. D.; Horton, G. R.: The Thermal Decomposition of Thorium(IV), Uranium(IV), and the Rare-Earth Metal(III) Oxalate Hydrates - Differential Thermal Analysis and Weight-Loss Studies, J Inorg Nucl Chem 1961, 17, 280-286.

33. Cetisli, H.; Cilgi, G. K.; Donat, R.: Thermal and kinetic analysis of uranium salts Part 1. Uranium (VI) oxalate hydrates, J Therm Anal Calorim 2012, 108, 1213-1222.

34. Dash, S.; Krishnan, R.; Kamruddin, M.; Tyagi, A. K.; Raj, B.: Temperature programmed decomposition of thorium oxalate hexahydrate, $J$ Nucl Mater 2001, 295, 281-289.

35. Hutchings, M. T.: High-Temperature Studies of $\mathrm{UO}_{2}$ and $\mathrm{ThO}_{2}$ Using Neutron-Scattering Techniques, J Chem Soc Farad T 2 1987, 83, 1083-1103.

36. Bertrand, M.; Plasari, E.; Lebaigue, O.; Baron, P.; Lamarque, N.; Ducros, F.: Hybrid LESmultizonal modelling of the uranium oxalate precipitation, Chem Eng Sci 2012, 77, 95104.

37. Abraham, F.; Arab-Chapelet, B.; Rivenet, M.; Tamain, C.; Grandjean, S.: Actinide oxalates, solid state structures and applications, Coordin Chem Rev 2014, 266, 28-68.

38. Crossey, L. J.: Thermal-Degradation of Aqueous Oxalate Species, Geochim Cosmochim Ac 1991, 55, 1515-1527.

39. Martinez, J.; Clavier, N.; Mesbah, A.; Audubert, F.; Le Goff, X. F.; Vigier, N.; Dacheux, N.: An original precipitation route toward the preparation and the sintering of highly reactive uranium cerium dioxide powders, $J$ Nucl Mater 2015, 462, 173-181.

40. Rai, D.; Felmy, A. R.; Ryan, J. L.: Uranium(IV) Hydrolysis Constants and Solubility Product of $\mathrm{UO}_{2} \cdot \mathrm{xH}_{2} \mathrm{O}(\mathrm{am})$, Inorg Chem 1990, 29, 260-264.

41. McEachern, R. J.; Taylor, P.: A review of the oxidation of uranium dioxide at temperatures below $400^{\circ} \mathrm{C}, \mathrm{J}$ Nucl Mater 1998, 254, 87-121.

42. Rousseau, G.; Desgranges, L.; Charlot, F.; Millot, N.; Niepce, J. C.; Pijolat, M.; Valdivieso, F.; Baldinozzi, G.; Berar, J. F.: A detailed study of $\mathrm{UO}_{2}$ to $\mathrm{U}_{3} \mathrm{O}_{8}$ oxidation phases and the associated rate-limiting steps, $J$ Nucl Mater 2006, 355, 10-20.

43. Leinders, G.; Pakarinen, J.; Delville, R.; Cardinaels, T.; Binnemans, K.; Verwerft, M.: Low-Temperature Oxidation of Fine $\mathrm{UO}_{2}$ Powders: A Process of Nanosized Domain Development, Inorg Chem 2016, 55, 3915-3927.

44. Desgranges, L.; Baldinozzi, G.; Rousseau, G.; Niepce, J. C.; Calvarin, G.: Neutron Diffraction Study of the in Situ Oxidation of $\mathrm{UO}_{2}$, Inorg Chem 2009, 48, 7585-7592.

45. Cooper, R. I.; Willis, B. T. M.: Refinement of the structure of $\beta-\mathrm{U}_{4} \mathrm{O}_{9}, A c t a$ Crystallographica a-Foundation and Advances 2004, 60, 322-325. 
46. Leinders, G.; Cardinaels, T.; Binnemans, K.; Verwerft, M.: Accurate lattice parameter measurements of stoichiometric uranium dioxide, J Nucl Mater 2015, 459, 135-142.

47. Blackburn, P. E.; Weissbart, J.; Gulbranson, E. A.: Oxidation of Uranium Dioxide, J Phys Chem-Us 1958, 62, 902-908.

48. Cardinaels, T.; Govers, K.; Vos, B.; Van den Berghe, S.; Verwerft, M.; de Tollenaere, L.; Maier, G.; Delafoy, C.: Chromia doped $\mathrm{UO}_{2}$ fuel: Investigation of the lattice parameter, $J$ Nucl Mater 2012, 424, 252-260.

49. Janeczek, J.; Ewing, R. C.: Structural Formula of Uraninite, J Nucl Mater 1992, 190, 128132.

50. Janeczek, J.; Ewing, R. C.: X-Ray-Powder Diffraction Study of Annealed Uraninite, J Nucl Mater 1991, 185, 66-77.

51. Gronvold, F.: High-Temperature X-Ray Study of Uranium Oxides in the $\mathrm{UO}_{2}-\mathrm{U}_{3} \mathrm{O}_{8}$ Region, J Inorg Nucl Chem 1955, 1, 357-370.

52. Hoekstra, H. R.; Santoro, A.; Siegel, S.: The Low Temperature Oxidation of $\mathrm{UO}_{2}$ and $\mathrm{U}_{4} \mathrm{O}_{9}$, J Inorg Nucl Chem 1961, 18, 166-178.

53. Claparede, L.; Clavier, N.; Dacheux, N.; Mesbah, A.; Martinez, J.; Szenknect, S.; Moisy, P.: Multiparametric Dissolution of Thorium-Cerium Dioxide Solid Solutions, Inorg Chem 2011, 50, 11702-11714.

54. Bouexiere, D.; Popa, K.; Walter, O.; Cologna, M.: Kinetic study on the grain growth of $\mathrm{PuO}_{2}$ nanocrystals, Rsc Adv 2019, 9, 6542-6547.

55. Leinders, G.; Bes, R.; Pakarinen, J.; Kvashnina, K.; Verwerft, M.: Evolution of the Uranium Chemical State in Mixed-Valence Oxides, Inorg Chem 2017, 56, 6784-6787.

56. Gueneau, C.; Baichi, M.; Labroche, D.; Chatillon, C.; Sundman, B.: Thermodynamic assessment of the uranium-oxygen system, $J$ Nucl Mater 2002, 304, 161-175.

57. Balakrishna, P.; Varma, B. P.; Krishnan, T. S.; Mohan, T. R. R.; Ramakrishnan, P.: Thorium Oxide - Calcination, Compaction and Sintering, J Nucl Mater 1988, 160, 88-94.

58. ASTM, Standard Specification for Nuclear-Grade, Sinterable Uranium Dioxide Powder. In West Conshohocken, PA, 2016; Vol. ASTM C753-16a.

59. Plasil, J.: The crystal structure of uranyl-oxide mineral schoepite, $\left[\left(\mathrm{UO}_{2}\right)_{4} \mathrm{O}(\mathrm{OH})_{6}\right]\left(\mathrm{H}_{2} \mathrm{O}\right)_{6}$, revisited, $J$ Geosci-Czech 2018, 63, 65-73.

60. Nakashima, S.: Kinetics and Thermodynamics of U-Reduction by Natural and Simple Organic-Matter, Org Geochem 1992, 19, 421-430.

61. Nakashima, S.: Complexation and Reduction of Uranium by Lignite, Sci Total Environ 1992, 118, 425-437. 